\title{
Systematics and biogeography of Sternarchellini (Gymnotiformes: Apteronotidae): Diversification of electric fishes in large Amazonian rivers
}

\author{
Stephen J. Ivanyisky III and James S. Albert
}

The Sternarchellini (Gymnotiformes, Apteronotidae) is a clade of 10 electric fish species that inhabit deep river channels of the Amazon and Orinoco basins, attain moderate adult body sizes (15-50 cm TL), and have a predatory life style. Here we trace the evolutionary origin and diversification of Sternarchellini using standard phylogenetic and biogeographic procedures and a dataset of 70 morphological characters. The main results are: 1) the genus Sternarchella includes both species currently assigned to the genus Magosternarchus; and 2) neither of the multi-species assemblages of Sternarchellini in the Amazon and Orinoco basins are monophyletic. Historical biogeographic analysis suggests that sternarchelline evolution was linked to the large-scale river capture event that formed the modern Amazon and Orinoco basins, i.e. the Late Miocene rise of the Vaupes structural arch and concomitant breaching of the Purus structural arch. This event is hypothesized to have contributed to formation of the modern sternarchelline species, and to the formation of the modern basin-wide sternarchelline species assemblages. The results indicate that cladogenesis (speciation) and anagenesis (adaptive evolution) were decoupled processes in the evolution of Sternarchellini.

Sternarchellini (Gymnotiformes, Apteronotidae) é um clado de 10 espécies de peixes elétricos que habitam canais profundos de rios das bacias do Amazonas e Orinoco, que atingem um tamanho moderado quando adultos (15-50 cm CT), e possuem hábito predatório. Rastreamos a origem evolutiva e diversificação de Sternarchellini utilizando técnicas filogenéticas e biogeográficas padrões e um conjunto de dados de 70 caracteres morfológicos. Os principais resultados são: 1) o gênero Sternarchella inclui duas espécies atualmente atribuídas ao gênero Magosternarchus; e 2) as assembleias de multi-espécies de Sternarchellini nas bacias Amazônica e do Orinoco não formam grupos monofiléticos. A análise biogeográfica histórica sugere que a evolução do Sternarchellini esteve ligada ao evento de captura de rio de grande escala que formou as atuais bacias do Amazonas e Orinoco, i.e., o soerguimento do arco estrutural Vaupés no Mioceno Superior e o rompimento concomitante do arco estrutural Purus. É proposto que esse evento contribuiu para o surgimento das espécies atuais de Sternarchellini, e para a formação das assembleias modernas de espécies de Sternarchellini com ampla distribuição nas bacias. Os resultados indicam que cladogênese (especiação) e anagenêse (evolução adaptativa) foram processos desacoplados na evolução de Sternarchellini.

Key words: Ecological specialization, Evolution, Historical Biogeography, Neotropical, Osteology.

\section{Introduction}

The Sternarchellini (Gymnotiformes: Apteronotidae) is a clade of medium-sized (15-50 cm TL) knife-shaped (culteriform) electric fishes that inhabit deep river channels in tropical South America (Lundberg et al., 1996; Albert, 2001). Sternarchellines inhabit the main stems of the Amazon and Orinoco rivers and some of their larger lowland tributaries, where they are predators of small aquatic animals (Albert \& Crampton, 2005a). The genus Sternarchella includes some of the most abundant species of electric fishes that live in deep channels of the Amazon and Orinoco basins (Lundberg et al., 2013). Sternarchellines are an important food source for large river catfishes, and therefore contribute to the food web, supporting a major fishery of the region (Lundberg \& Lewis, 1987; Crampton, 1996).

Sternarchelline species possess a suite of morphological and behavioral phenotypes associated with active locomotion and foraging in swiftly flowing riverine water. These traits include: robust oral and pharyngeal jaws with many large conical teeth, a reticulated skeleton riddled with lipid filled cavities, and large lamellar attachment sites for axial and jaw muscles. Sternarchellines also produce a very high-frequency wave-type electric organ discharge (EOD) for use in object location and social communication, generating discharge frequencies ranging from about 940 to 2,180 cycles per second

Department of Biology, University of Louisiana at Lafayette, Lafayette LA, USA, 70501-2451. jalbert@louisiana.edu (corresponding author) 
(Hz). Some sternarchellines produce the highest electrical discharge frequencies of all electric fishes, with the electrogenic system of $S$. schotti being the fastest known biological oscillator (Albert \& Crampton, 2005b; Crampton \& Albert, 2006).

The Sternarchellini is a member of the Apteronotidae, the most species-rich family of Gymnotiformes, with 87 currently valid species. The Apteronotidae is an ancient group that originated in the early Cenozoic or late Cretaceous (Albert, 2001; Near et al., 2012) and which ranges over the whole extent of the South American platform, from northern Argentina to Panamá (Eigenmann \& Allen, 1922). Within Apteronotidae, Sternarchellini is a member of the Navajini, including the genera Compsaraia, Magosternarchus, Porotergus, Sternarchella, and Sternarchogiton (Albert, 2001). Members of the Navajini are highly specialized for living in the deep channels (10 - 50 meters) of large lowland Amazonian rivers (stream orders 610). The Navajini, from the Spanish word navaja, blade, is named for its highly derived body shape, strongly compressed laterally, semi-translucent with a pink hue in life, with few or no melanophores and few large scales over most of the body surface, large thin translucent and rhomboid-shaped scales along the lateral line, and a relatively deep body with long bony supports (anal-fin pterygiophores) used to anchor the muscles that undulate the elongate anal fin. The character definitions for Sternarchellini are from Albert (2001), amended herein.

Sternarchellini is currently known from nine valid species and one undescribed species allotted to three genera: Magosternarchus with two species (M. duccis and M. raptor, Lundberg et al., 1996), Pariosternarchus with one species, and Sternarchella with seven species (Albert, 2001; Albert \& Crampton, 2006; Table 1). Magosternarchus is notable in having one of the most specialized head and jaw morphologies for grasping prey items within the Apteronotidae. Magosternarchus also exhibit extreme behaviors, such as feeding on the tails of other gymnotiform fishes (Lundberg et al., 1996), and discharging electric signals at frequencies up to 2,000 Hz (Albert \& Crampton, 2005b). The monotypic Pariosternarchus amazonensis (Albert \& Crampton, 2006) has a very broad and flat ventral surface of the head, with greatly expanded mandibular laterosensory canals, presumably used in object detection on the river benthos. Species of Magosternarchus and Pariosternarchus are rare in collections, and are presumably present in low densities in the wild. Sternarchella is known from six valid species: $S$. calhamazon (Lundberg et al., 2013), S. orinoco (Mago-Leccia, 1994), S. orthos (Mago-Leccia, 1994), S. schotti (Steindachner, 1868), S. sima (Starks, 1913), S. terminalis (Eigenmann \& Allen, 1942), and one undescribed species (Sternarchella sp. A, Crampton, 2011). Most species of Sternarchella (except $S$. schotti and Sternarchella sp. A) are commonly taken in middle and bottom water trawls in large rivers of the Amazon and Orinoco basins, and these species are presumably present in high abundances in these habitats.
The genus Sternarchella was introduced by Eigenmann (in Eigenmann and Ward, 1905) to include S. schotti (Steindachner, 1868), originally described as Sternarchus schotti from Barra do Rio Negro (Manaus), Brazil. Steindachner (1868) also described S. capanemae from Manaus, but this is now treated as a junior synonym of $S$. schotti (Lundberg et al., 2013: 170-171). Sternarchella sima (Starks, 1913) was described from the vicinity of Pará, Brazil. Sternarchella terminalis (Eigenmann \& Allen, 1922) was described from Iquitos, Peru, although originally placed in another apteronotid genus, Porotergus. Sternarchella curvioperculata (Godoy, 1968) was described from the Rio Mogi-Guassu in the upper rio Paraná basin, and subsequently placed in the genus Porotergus by Mago-Leccia (1994). Sternarchella curvioperculata was not found to share characters with other Sternarchella species or Magosternarchus in a subsequent morphological study by Triques (2005). Sternarchella orthos and S. orinoco were described by Mago-Leccia (1994) from localities in Orinoco basin, Venezuela. Sternarchella calhamazon was recently described by Lundberg et al. (2013) as the most abundant species of apteronotid electric fish in the Amazonian river channels.

Understanding the phylogeny and historical biogeography of Sternarchellini will contribute to answering some important questions in Neotropical Ichthyology. How did so many apteronotid species come to inhabit the relatively small habitat space presented by deep river channels of lowland Amazonia? Does the deep channel fauna represent a case of adaptive radiation by means of ecological specialization? What are the relative roles of geographic isolation and ecological specialization in the origin of these species, and in the formation of the basin-wide assemblages? Here we provide a phylogenetic revision of the Sternarchellini from examination of specimens representing all known species, and use the results to help interpret its history of biogeographic and adaptive evolution.

\section{Material and Methods}

Material used in this study included 69 museum lots with 239 specimens, including 57 lots of ingroup taxa with 220 specimens. Specimens examined are listed in Appendix 1. Museum abbreviations are: American Museum of Natural History (AMNH), Academy Natural Sciences, Philadelphia (ANSP), Field Museum of Natural History (FMNH), Museum University San Marcos (MUSM), California Academy of Sciences-Stanford University (CAS-SU), University of Florida (UF), University of Michigan Museum of Zoology (UMMZ), and United States National Museum (USNM).

External characters, morphometrics, and meristics, were examined from specimens of 16 apteronotid species, all originally fixed in 10\% formalin and preserved in $70 \%$ ethanol. Morphometric methods were modified for Sternarchella species from Albert (2001). Morphometric measurements are: 
Table 1. Summary of taxonomic data on valid species of Sternarchellini.

\begin{tabular}{|c|c|c|c|c|c|}
\hline Species & Year & Author(s) & Type locality & State, Country & Basin \\
\hline Magosternarchus duccis & 1996 & Lundberg et al. & Rio Branco near confluence Rio Negro & Roraima, Brazil & Amazon \\
\hline Magosternarchus raptor & 1996 & Lundberg et al. & Rio Solimões, near confluence Rio Purús & Amazonas, Brazil & Amazon \\
\hline Pariosternarchus amazonensis & 2006 & Albert \& Crampton & Mamirauá reserve, Alvarães near Tefé & Amazonas, Brazil & Amazon \\
\hline Sternarchella calhamazon & 2013 & Lundberg et al. & $\begin{array}{l}\text { rio Madeira, } 35 \mathrm{~km} \text { above confluence with } \\
\text { rio Amazonas }\end{array}$ & Amazonas, Brazil & Amazon \\
\hline Sternarchella orinoco & 1994 & Mago-Leccia & Delta of Rio Orinoco at Isla Iguana & Amacuro, Venezuela & Orinoco \\
\hline Sternarchella orthos & 1994 & Mago-Leccia & Rio Apure near mouth Rio Boqueronis & Apure, Venezuela & Orinoco \\
\hline Sternarchella schotti & 1868 & Steindachner & Mouth of Rio Negro at Manaus & Amazonas, Brazil & Amazon \\
\hline Sternarchella sima & 1913 & Starks & Pará (Belem) & Pará, Brazil & Amazon \\
\hline Sternarchella terminalis & 1942 & Eigenmann \& Allen & near Iquitos & Loreto, Peru & Amazon \\
\hline
\end{tabular}

total length (TL), length to the end of the anal fin (LEA), anal fin length (AF), head length (HL), preorbital distance (PR), eye diameter (ED), postorbital distance (PO), interorbital distance (IO), mouth width (MW), head depth through the nape (HD1), head depth through the eye (HD2), head width (HW), length from anus to anal-fin origin (PA) (Fig. 1); body depth through end of the body cavity (BD), and body width at the end of the body cavity (BW) are not depicted in Fig. 1. Specimens with damaged or incompletely regenerated tails were not measured for TL. Due to proportion of specimens with incompletely regenerated tails, HL was used as the standard measure of overall specimen size. PC1 may also be used as a measure of overall body size. Morphometric data are summarized in Table 2 .

Principal Components Analyses (PCA) including specimens of all Sternarchella species were conducted with the software package PAST (Hammer et al., 2001) in order to understand morphometric variation and to discover phenotypic discontinuities in a multivariate morphospace.
Twelve log-transformed morphometric characters were used in the PCA. Total length, LEA, and AF measurements were not used due to the occurrence of incompletely regenerated tails in several specimens. The first principal axis (PC1) variable loadings were all positive and varied little in magnitude. PC1 was inferred as a general size factor (Jolicoeur \& Mosimann, 1960; Jolicoeur, 1963; McElroy \& Douglas, 1995).

Clearing and staining for bone and cartilage followed the procedure of Taylor \& Van Dyke (1985). The following modification to the clearing and staining procedure was utilized to manage the high lipid content of many Sternarchellini: before starting the protocol for clearing and staining, specimens were placed in xylene for one day. Specimens were then washed in three separate 95\% ethanol baths to remove xylene from tissues. Specimens were subsequently transferred directly to Alcian Blue solution to maximize uptake of the hydrophobic stain. Cleared and stained specimens were stored in a final solution of $70 \%$ glycerol (with thymol). Dissection of cleared and stained specimens

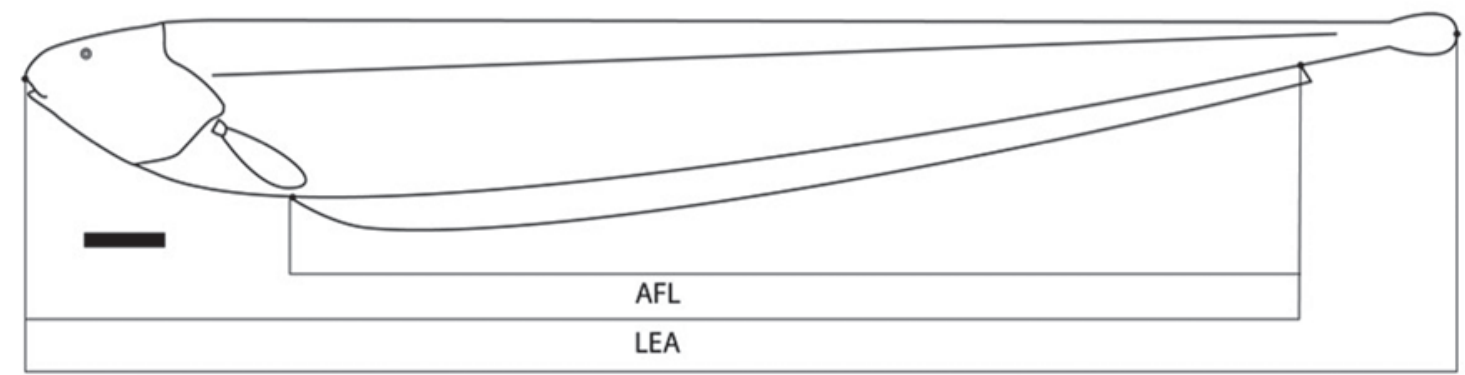

TL
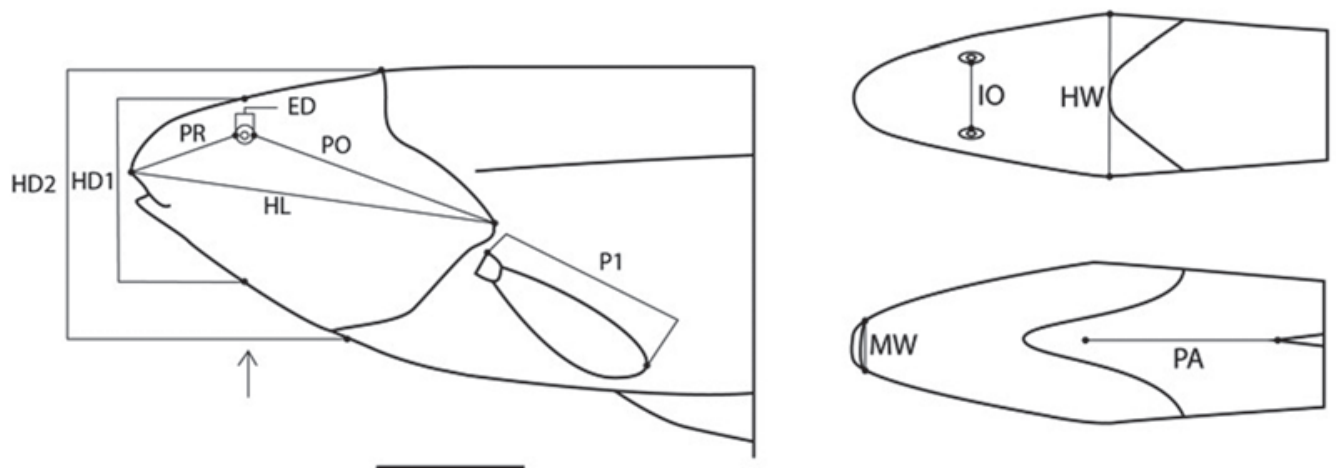

Fig. 1. Line drawing of the holotype of Sternarchella sima (SU 22220), illustrating landmarks used in morphometric analysis. 
Table 2. Summary of morphometric data collected from 217 specimens in six Sternarchella species.

\begin{tabular}{|c|c|c|c|c|c|c|}
\hline & \multicolumn{3}{|c|}{ S. calhamazon } & \multicolumn{3}{|c|}{ S. orinoco } \\
\hline & $\mathrm{n}$ & range & avg. & $\mathrm{n}$ & range & avg. \\
\hline $\mathrm{HL}$ & 52 & $12.8-30.6$ & 24.1 & 37 & $13.4-33.5$ & 20.5 \\
\hline PR\% & 52 & $0.29-0.33$ & 0.31 & 37 & $0.28-0.32$ & 0.3 \\
\hline ED\% & 52 & $0.06-0.08$ & 0.07 & 37 & $0.05-0.08$ & 0.06 \\
\hline $\mathrm{PO} \%$ & 52 & $0.60-0.66$ & 0.64 & 37 & $0.64-0.70$ & 0.67 \\
\hline IO\% & 52 & $0.18-0.23$ & 0.2 & 37 & $0.14-0.21$ & 0.17 \\
\hline MW\% & 52 & $0.17-0.23$ & 0.19 & 37 & $0.17-0.23$ & 0.21 \\
\hline HD1\% & 52 & $0.57-0.67$ & 0.62 & 37 & $0.44-0.53$ & 0.48 \\
\hline HD2\% & 52 & $0.72-0.85$ & 0.78 & 37 & $0.63-0.76$ & 0.70 \\
\hline HW\% & 52 & $0.38-0.51$ & 0.43 & 37 & $0.36-0.49$ & 0.42 \\
\hline PA\% & 52 & $0.51-0.77$ & 0.63 & 37 & $0.17-0.46$ & 0.31 \\
\hline BD\% & 52 & $0.92-1.17$ & 1.02 & 37 & $0.69-1.20$ & 0.84 \\
\hline BW\% & 51 & $0.26-0.38$ & 0.32 & 36 & $0.16-0.32$ & 0.21 \\
\hline \multirow[t]{3}{*}{ BW/BD } & 51 & $0.26-0.35$ & 0.31 & 36 & $0.20-0.34$ & 0.25 \\
\hline & \multicolumn{3}{|c|}{ S. sima } & \multicolumn{3}{|c|}{ S. orthos } \\
\hline & $\mathrm{n}$ & range & avg. & $\mathrm{n}$ & range & avg. \\
\hline $\mathrm{HL}$ & 19 & $14.6-25.4$ & 19.8 & 54 & $16.4-43.9$ & 30.3 \\
\hline PR\% & 19 & $0.28-0.35$ & 0.31 & 54 & $0.29-0.34$ & 0.32 \\
\hline ED\% & 19 & $0.05-0.07$ & 0.06 & 54 & $0.05-0.08$ & 0.06 \\
\hline PO\% & 19 & $0.63-0.71$ & 0.66 & 54 & $0.60-0.66$ & 0.63 \\
\hline IO\% & 19 & $0.22-0.26$ & 0.24 & 54 & $0.13-0.19$ & 0.16 \\
\hline MW\% & 19 & $0.16-0.22$ & 0.20 & 54 & $0.17-0.22$ & 0.19 \\
\hline HD1\% & 19 & $0.49-0.64$ & 0.57 & 54 & $0.44-0.61$ & 0.53 \\
\hline HD2\% & 19 & $0.72-0.88$ & 0.79 & 54 & $0.60-0.77$ & 0.68 \\
\hline HW\% & 19 & $0.43-0.52$ & 0.48 & 54 & $0.31-0.51$ & 0.41 \\
\hline PA\% & 19 & $0.35-0.59$ & 0.45 & 54 & $0.34-0.68$ & 0.50 \\
\hline BD\% & 19 & $0.93-1.27$ & 1.07 & 54 & $0.75-1.14$ & 0.92 \\
\hline BW\% & 19 & $0.24-0.42$ & 0.33 & 54 & $0.16-0.38$ & 0.27 \\
\hline \multirow{3}{*}{ BW/BD } & 19 & $0.26-0.35$ & 0.31 & 54 & $0.20-0.34$ & 0.29 \\
\hline & \multicolumn{3}{|c|}{ S. terminalis } & \multicolumn{3}{|c|}{ S. schotti } \\
\hline & $\mathrm{n}$ & range & avg. & $\mathrm{n}$ & range & avg. \\
\hline $\mathrm{HL}$ & 45 & $15.9-41.6$ & 30.3 & 10 & $18.0-38.2$ & 24.3 \\
\hline PR\% & 45 & $0.29-0.37$ & 0.32 & 10 & $0.29-0.32$ & 0.32 \\
\hline ED\% & 45 & $0.05-0.07$ & 0.06 & 10 & $0.07-0.09$ & 0.08 \\
\hline PO\% & 45 & $0.60-0.66$ & 0.63 & 10 & $0.59-0.63$ & 0.61 \\
\hline IO\% & 45 & $0.12-0.24$ & 0.16 & 10 & $0.12-0.16$ & 0.14 \\
\hline MW\% & 45 & $0.16-0.25$ & 0.19 & 10 & $0.16-0.19$ & 0.20 \\
\hline HD1\% & 45 & $0.47-0.66$ & 0.53 & 10 & $0.51-0.54$ & 0.52 \\
\hline HD2\% & 45 & $0.62-0.84$ & 0.68 & 10 & $0.63-0.71$ & 0.66 \\
\hline HW\% & 45 & $0.36-0.59$ & 0.41 & 10 & $0.33-0.39$ & 0.37 \\
\hline PA\% & 45 & $0.32-0.57$ & 0.50 & 10 & $0.30-0.67$ & 0.45 \\
\hline BD\% & 45 & $0.78-1.18$ & 0.92 & 10 & $0.66-0.93$ & 0.82 \\
\hline BW\% & 45 & $0.18-0.38$ & 0.27 & 8 & $0.16-0.30$ & 0.25 \\
\hline $\mathrm{BW} / \mathrm{BD}$ & 45 & $0.22-0.34$ & 0.29 & 8 & $0.24-0.33$ & 0.29 \\
\hline
\end{tabular}

followed the method outlined by Weitzman (1974) using microdissection tools under an Olympus SZX - 12 dissecting stereomicroscope equipped with a camera lucida. Bones were disarticulated to functional groups (neurocranium, suspensorium, pectoral girdle) or to individual bony elements. Specimens from a total of 16 species were dissected and coded for phylogenetic analysis. Cleared and stained specimens were examined and illustrated following conventions for gymnotiform osteology (Albert, 2001). Outlines and standardized features of each bone were traced in lateral and medial views, and images were digitized using an Epson Perfection V300 scanner and edited in Adobe Photoshop and Illustrator. Illustrations of the neurocranium in dorsal, lateral, and ventral views are provided in Figs. 2-3, and of the suspensorium in lateral view in Figs. 4-5.

Characters were selected based on their phylogenetic informativeness (Pimentel \& Riggins, 1987) and analyzed

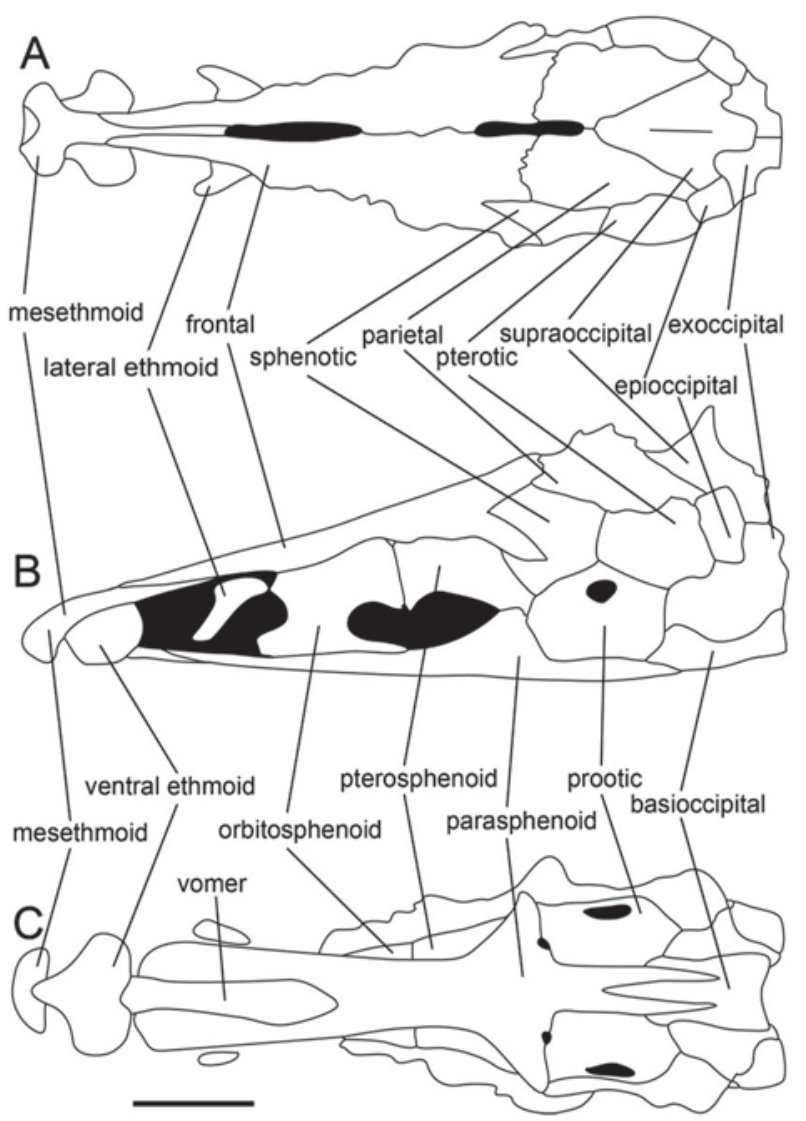

Fig. 2. Diagrammatic representation of neurocranium of Sternarchella terminalis (MUSM 45236, 235 mm TL). A. Dorsal view. B. Lateral view. C. Ventral view. Scale bar $=5 \mathrm{~mm}$.

using Maximum Parsimony (MP). Osteological nomenclature follows Patterson (1975) and Albert (2001). All characters were coded from mature specimens, inferred from the degree of ossification in the sphenoid region of the neurocranium and coracoid region of the pectoral girdle (Albert, 2001). The data matrix is provided in Appendix 2. The general principles of phylogenetic systematics outlined by Hennig (1966) and Wiley (1981) were employed during parsimony analysis. Microsoft Excel (2010) and MacClade 4.08 PPC (Madison \& Madison, 2005) software packages were used to assemble a data matrix of 16 taxa and 70 morphological characters. Character states were polarized using six apteronotid outgroup species, as per the tree topology of Albert (2001).

A heuristic search with Tree-Bisection-Reconnection (TBR) algorithm was performed using PAUP* v. 4.0 b10 (Swofford, 2003) in the parsimony analysis. All multistate characters were treated as unordered. Bremer Support (Bremer, 1988) was conducted using TNT (Goloboff et al., 2008) to assess branch support, using 1000 replicates. A bootstrap analysis (resampling characters with replacement; Hillis \& Bull, 1993) was also performed to assess branch support, using 1000 replicates. Consistency (CI) and retention indexes (RI) are provided as measures of character fit to a given tree topology (Farris, 1989). 

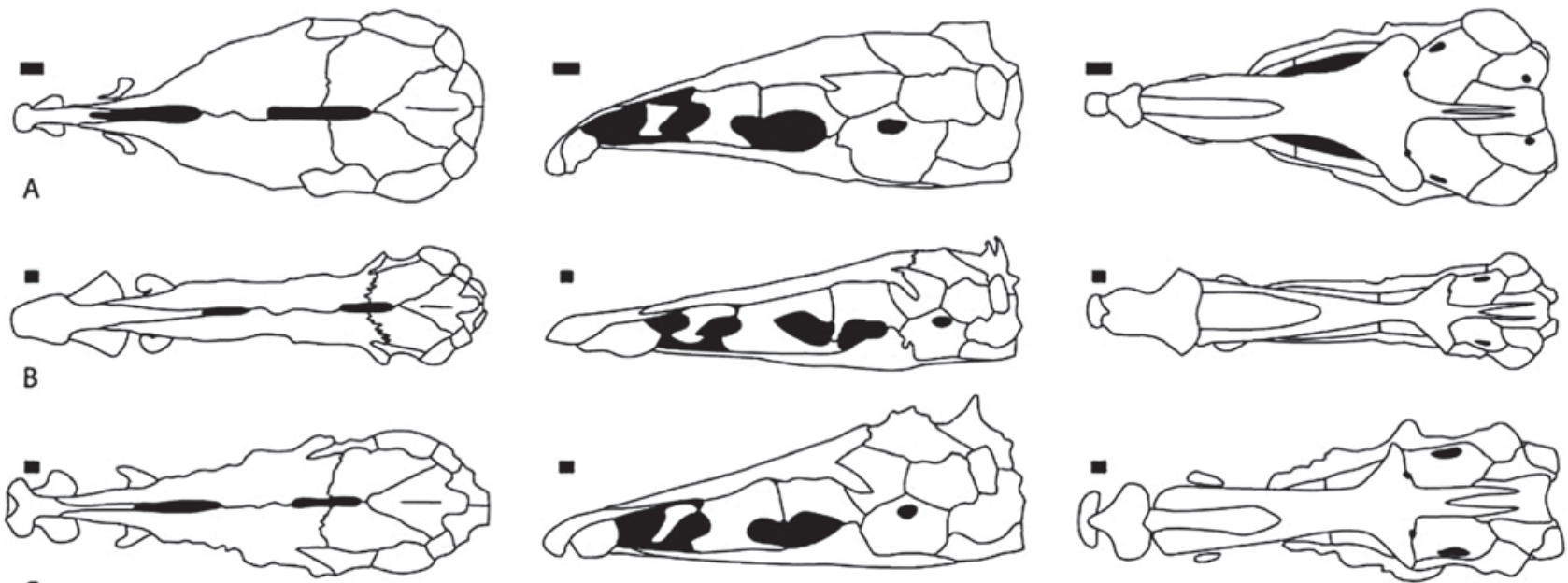

C
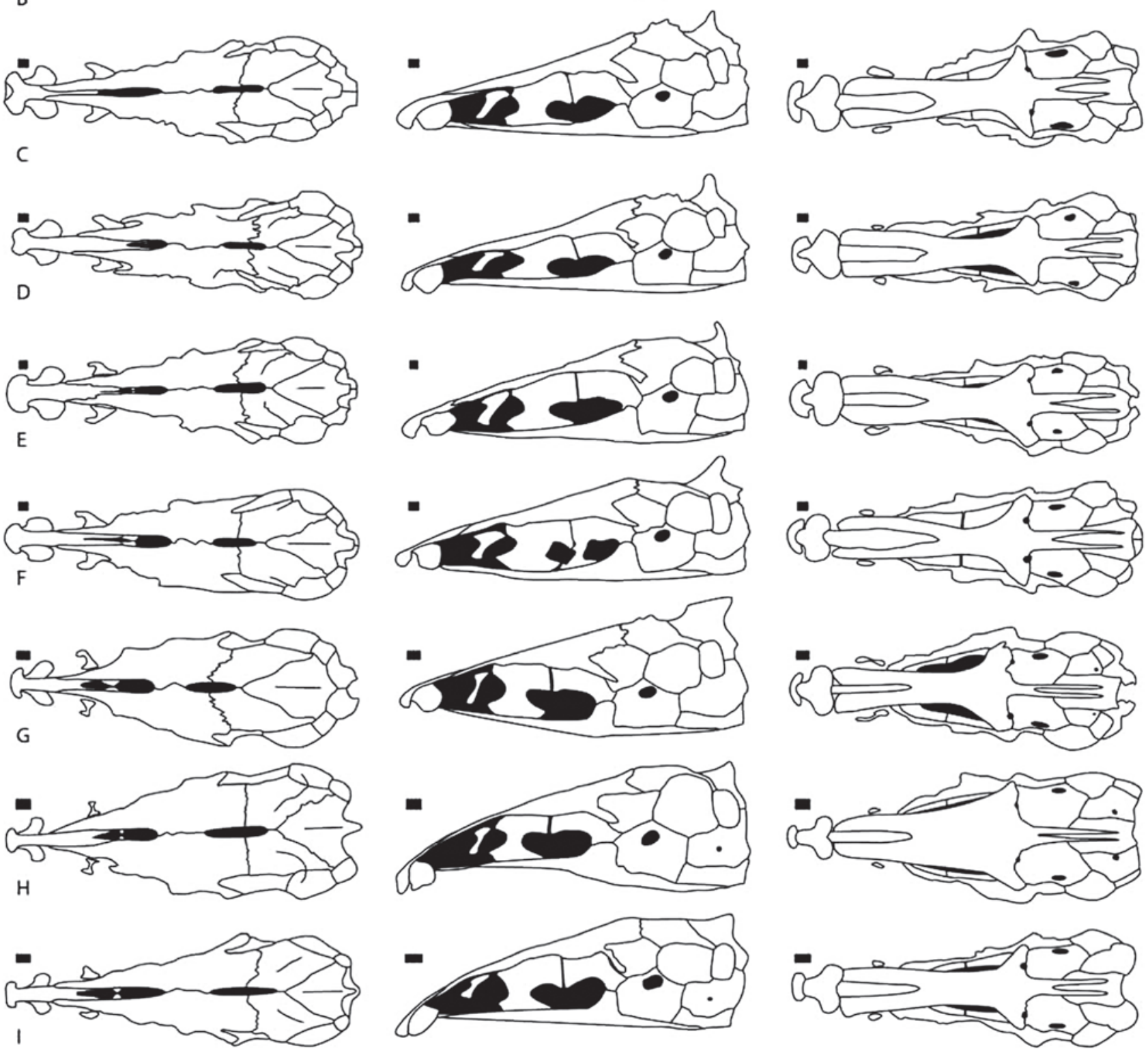

Fig. 3. Diagrammatic representations of neurocrania in sternarchelline species. Dorsal, lateral, and ventral views in left, middle and right columns, respectively. Species arranged from top to bottom: A. Pariosternarchus amazonensis, ANSP 192996. B. Magosternarchus raptor, UF 116762. C. Sternarchella terminalis, MUSM 45236. D. S. orthos, USNM 228725. E. Sternarchella n. sp. A. F. Sternarchella schotti, UF 11657. G. S. calhamazon, MUSM 45234. H. S. sima, ANSP 192107. I. S. orinoco, USNM 228727. Note neurocrania range from rounded and gracile (paedomorphic) at top, to elongate and robust (peramorphic) at bottom. Scale bars $=5 \mathrm{~mm}$. 


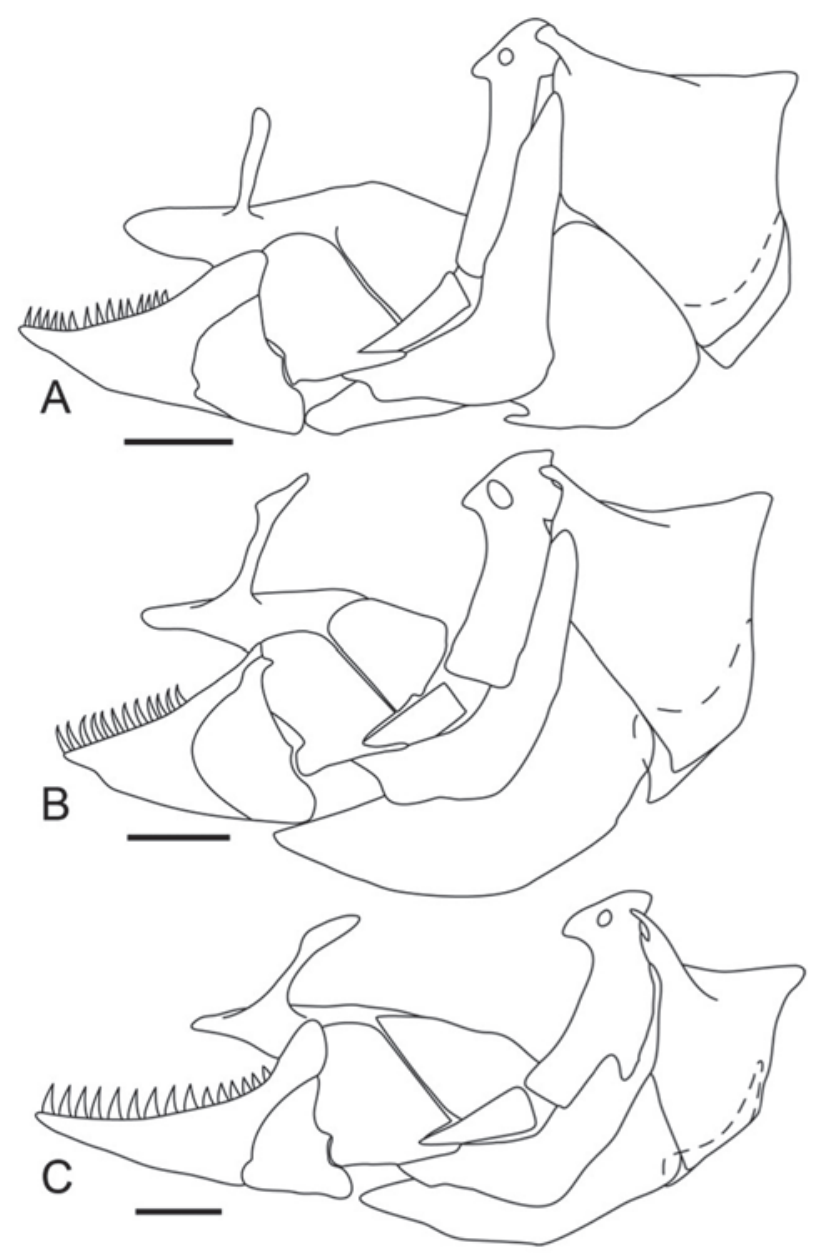

Fig. 4. Lateral view of suspensorium in selected sternarchelline species. A. Sternarchella schotti, UF 116570 . B. S. terminalis, MUSM 45236. C. Magosternarchus raptor, UF 116762. Scale bars $=3 \mathrm{~mm}$.

\section{Results}

Three separate PCAs were run on the morphometric data set. The first analysis examined only the species present in the rio Amazon basin (Fig. 6). The results of this analysis indicate that Sternarchella sima, S. schotti, and S. calhamazon do not overlap in the multivariate morphospace. However, S. terminalis does partially overlap in morphospace with some sympatric species. Morphological differences between S. sima and S. orinoco are evident from an almost complete segregation of the two species on the second PCA axis (Fig. 7). These differences are observed in the loading factors, which is dominated by two traits of head and body width: S. sima has more widely-set eyes (IO) than S. orinoco, and a broader body at the posterior margin of the body cavity (BW) (see also Table 2). The third PCA examined S. terminalis and $S$. orthos and recovered no distinguishable differences in PC1 or PC2 (Fig. 8). Only a single character was found in this study to be useful in differentiating $S$. terminalis from the Amazon basin and S. orthos from the Orinoco basin: large

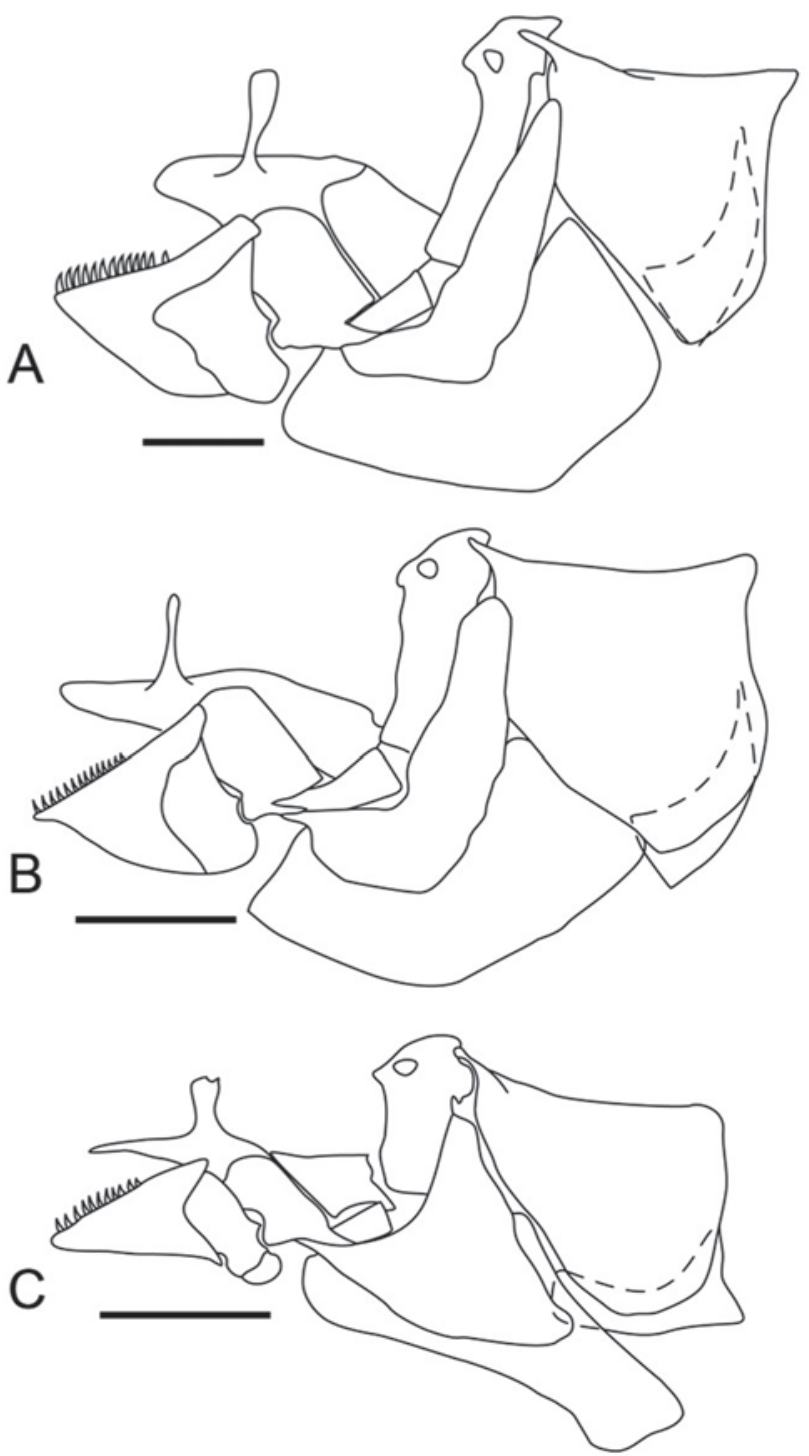

Fig. 5. Lateral view of suspensorium in selected sternarchelline species. A. Sternarchella calhamazon, MUSM uncat. B. S. sima, ANSP 192107. C. Pariosternarchus amazonensis, UF 129334. Scale bars $=3 \mathrm{~mm}$.

scales above the lateral line (5-6 SAL) in S. orthos (see MagoLeccia, 1994:85), vs. small scales (7-9 SAL) in S. terminalis.

Two equally parsimonious trees of 138 steps were recovered in the analyses. In one of them, Sternarchella $\mathrm{n}$. sp. A is sister to S. terminalis, and in the other Sternarchella sp. A is sister to $S$. orthos. A strict consensus places Sternarchella sp. A in a trichotomy with $S$. terminalis and $S$. orthos (Fig. 9). Sternarchella is paraphyletic according to the phylogenetic analysis, since it includes $M$. raptor and $M$. duccis. Relatively high Bremer support and bootstrap values, which provide further confidence in the monophyly of Sternarchellini and more inclusive clades, are presented in Fig. 9. A summary of character state changes is provided in Appendix 3, and brief descriptions of the characters and character states are provided in Appendix 4. 

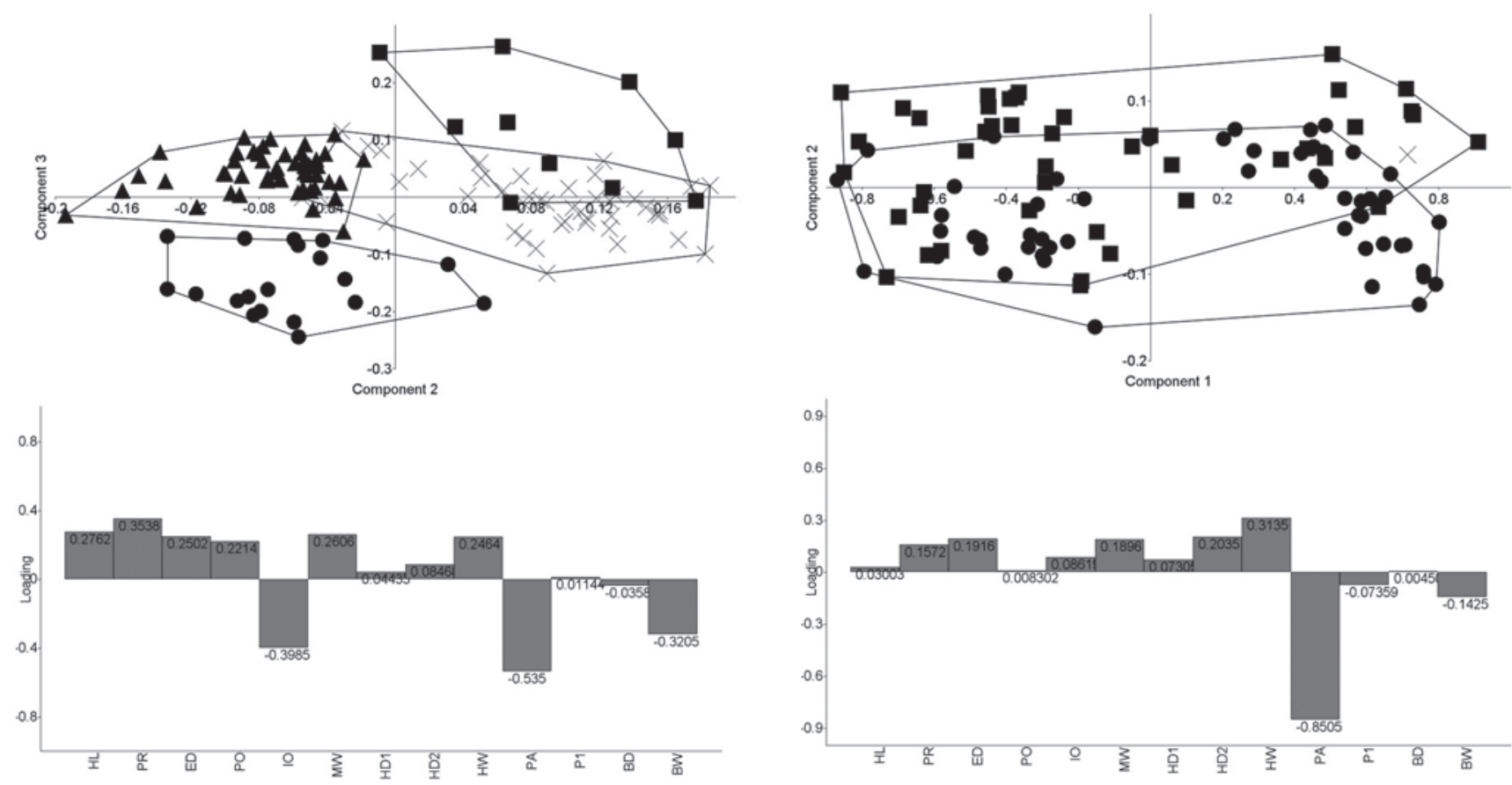

Fig. 6. Scatter plot of PC2 and PC3 for specimens representing four Sternarchella species from the Amazon basin $(n=126)$. Loadings of the 13 variables reported in lower panel. Sternarchella schotti represented as squares $(\mathrm{n}=10)$, S. sima as circles $(n=19)$, S. terminalis as Xs $(n=45), S$. n. sp. 1 as triangles $(n=52)$. Note this assemblage is not monophyletic. Morphometric data reported in Tables.

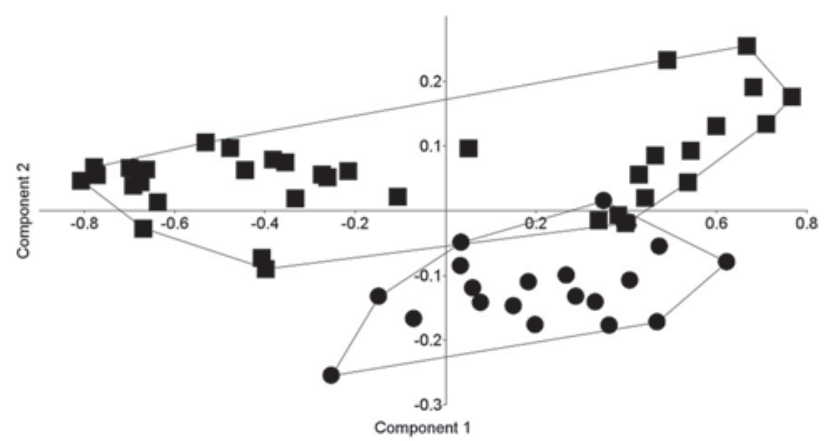

Fig. 8. PCA scatter plot of species in the $S$. terminalis species group. Loadings of all 13 variables for PC2 reported in lower panel. Sternarchella terminalis represented as squares $(\mathrm{n}=$ 45), S. orthos as circles $(\mathrm{n}=54)$, and Sternarchella sp. A represented as an $X(n=1)$.

\section{Clade diagnoses}

Here we provide diagnoses for eight clades, with clades names referring to lettered nodes in Fig. 9.

Clade $E$ is the Sternarchellini, which consists of all Sternarchella, Pariosternarchus, and Magosternarchus species. Monophyly of this clade is supported by 12 characters: MW at least 18\% HL; anterior shelf of maxilla absent (except in Magosternarchus), dentary longer than deep, dorsal margin of dentary slightly concave, supraoccipital crest exceeding dorsal margin of parietals, supraorbital canal not fused to frontals, endopterygoid process long contacting or fused to frontals, dorsal margin of opercle concave, first basibranchial fan or rod shaped as opposed to hour-glassed shaped except in $S$. calhamazon, basibranchial two not ossified except in $S$. schotti, fourth epibranchial post-medial bridge present, urohyal blade unossified or poorly ossified except for $S$. terminalis species group.

Clade $G$ is comprised of all Sternarchella and Magosternarchus species, and its monophyly is supported by six characters: premaxilla large in size, wider than maxilla, anterior hook of maxilla absent, ventral margin of descending blade of maxilla rounded, as opposed to straight (except in $M$. raptor), ventral ethmoid large and robust with a large fan shaped lateral process, dorsal-medial portion of orbitosphenoids in contact, seven or less large robust teeth present on hypobranchial 6.

Clade $H$ is comprised of S. schotti, S. calhamazon, Magosternarchus, and the "Sternarchella terminal mouth 


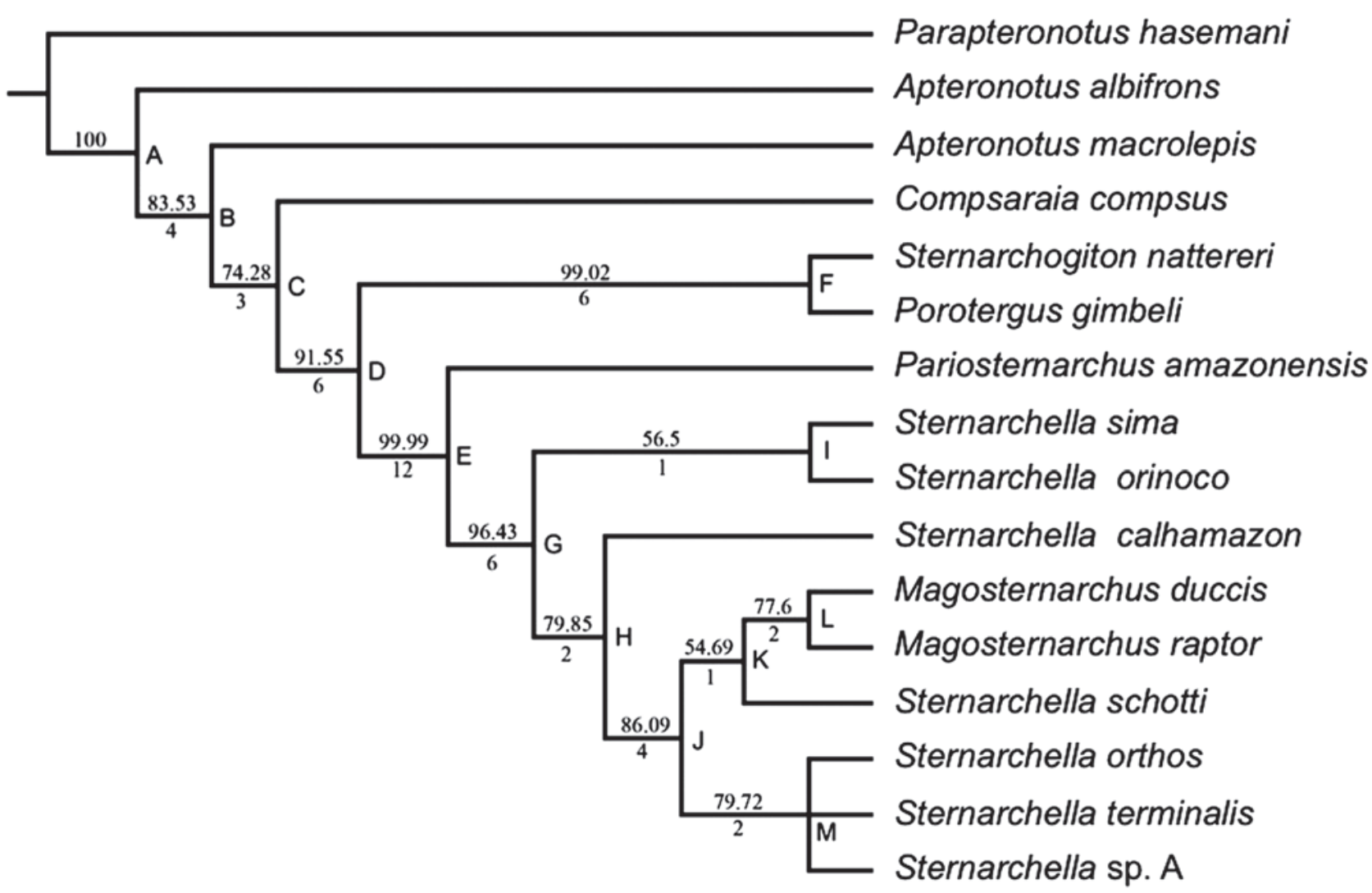

Fig. 9. Phylogenetic tree of Sternarchellini and closely related apteronotine species resulting from MP analysis of the data matrix in Appendix 3. Bootstrap values present above nodes and Bremer support values below nodes.

species group”, consisting of S. terminalis, S. orthos, and S. sp. A. The monophyly of this clade is supported by four characters: terminal or superior mouth placement, as opposed to subterminal, premaxilla triangular in shape, tip of endopterygoid process broad, and twelve or less teeth present on the pharyngobranchial, except in S. schotti and S. orthos. Unlike other Sternarchellini species, S. calhamazon possess an hour-glassed shaped first basibranchial. Sternarchella calhamazon also has a superior mouth.

Clade J consists of Magosternarchus, S. schotti, and the Sternarchella terminal mouth species group (Clade H), and its monophyly is supported by five characters: IO less than $20 \% \mathrm{HL}$, anterior portion of mesethmoid straight in lateral view, lateral ethmoid large and robust with an hourglass shape, supraoccipital crest deeply concave with a dorsallyoriented process at posterior margin, as opposed to an elongate blade, endopterygoid process forming an oblique angle with plane of endopterygoid.

Clade K is comprised of Magosternarchus and S. schotti and its monophyly is supported by a single unambiguous character state: presence of 14 or more precaudal vertebra. This clade is not well supported, with bootstrap values below $70 \%$, and a Bremer support value of 1 . Sternarchella schotti is unique among Sternarchellini species in having an eye diameter (EO) $8 \%$ or more of head length (HL), a mouth width
(MW) less than 18\% HL, a large flat space between reduced lateral parietal ridges, an ossified second basibranchial, 14 or more teeth present on the pharyngobranchial, and an elongate swim-bladder which extends posteriorly past the body cavity.

Clade I is the Sternarchella sima species group, comprised of $S$. sima and $S$. orinoco, and its monophyly is supported by four character states: PO large, over $67 \% \mathrm{HL}$, pectoral fin large, over $80 \% \mathrm{HL}$, four distinct rows of teeth present on the premaxilla, and three to four rows of teeth present on the dentary. Species of that clade also possesses ventrally placed mouths. Within the Sternarchella sima species group, S. sima and $S$. orinoco are distinguishable from one another by two characters: $S$. orinoco has a more narrow head (IO less than 20\% HL), while S. sima has a broader head (IO larger than 20\% HL). Sternarchella orinoco also has a longer body than $S$. sima, and a BW less than 21\% HL, whereas $S$. sima has a wider body with a BW greater than $21 \%$ HL. The overall difference in morphology between $S$. sima and S. orinoco is represented in a PCA, which largely do not overlap in the morphospace (Fig. 7).

Clade $L$ is comprised of the two Magosternarchus species. The monophyly of Clade $\mathrm{L}$ is supported by four characters: absence of a short gape, anterior shelf of maxilla present, anterior fontanel shorter than posterior fontanel, and a narrow orbitosphenoid. Magosternarchus raptor is 
diagnosed by six characters: PR greater than 35\% HL, BW less than $21 \% \mathrm{HL}$, terminal mouth position, ventral margin of the descending blade of the maxilla strait, as opposed to curved (which is the state in other Sternarchellini species), ventral process of the pterosphenoid present, and width of opercle about half as deep. Magosternarchus raptor is easily distinguished from other sternarchelline species by larger, more robust oral jaws. Magosternarchus duccis possess a small PO, unlike any other sternarchelline species. Magosternarchus duccis is readily distinguished from $M$. raptor by a superior mouth.

Clade $M$ is the Sternarchella terminal-mouth species group, and is comprised of $S$. terminalis, $S$. orthos, and $S$. calhamazon. The monophyly of Clade $\mathrm{M}$ is supported by three character states: terminal mouth position, three rows of teeth on premaxilla, and urohyal blade unossified or poorly ossified. A single character distinguishes $S$. terminalis from the other two species with a terminal mouth: a narrow orbitosphenoid.

\section{Discussion}

\section{Taxonomic status of Sternarchella from the Orinoco basin}

Results of the PCA analyses indicate that Sternarchella sima and S. orinoco exhibit distinct phenotypes (Fig. 7), whereas $S$. terminalis and $S$. orthos are morphologically indistinguishable according to the characters examined (Fig. 8). A preliminary analysis using geometric morphometric of head neurocranial shape in lateral views recovered similar results (K. Evans and J. Albert, pers. obs.), finding statistically significant differences between $S$. sima and S. orinoco $(\mathrm{P}<$ 0.001 ), and no significant differences between $S$. terminalis and $S$. orthos $(\mathrm{P}=0.1037)$. The osteological data reviewed here indicate that $S$. orthos has a narrower orbitosphenoid (character 33) and more pharyngobranchial teeth (character 59) than S. terminalis (14 or more vs. 13 or less). However, both of these characters may have dubious taxonomic value, being variable within many apteronotid species (Albert, 2001), and exhibiting relatively high homoplasy on the tree of Fig. 9 ( $C I=0.25$ and 0.20 , respectively). The reliability of these characters as diagnostic traits for $S$. terminalis therefore needs to be tested with larger sample sizes. Given the relatively poor geographic sampling of individuals from across the large range of these species, it seems premature to advance any formal nomenclatural changes, and we provisionally recognize $S$. orinoco and $S$. orthos from the Orinoco basin as valid species.

\section{Origin of the deep-channel electric fish fauna}

The Sternarchellini represents an excellent taxon in which to study the contributing roles of geography and ecology in the formation of the diverse and specialized deep-channel Neotropical fish fauna. In some clades of deep-channel apteronotids, several closely-related species occur together in sympatry and syntopy, such as in Adontosternarchus,
Porotergus, Sternarchella, Sternarchogiton, and Sternarchorhynchus (Crampton \& Albert, 2006; Crampton et al., 2011). Other gymnotiform clades are also diverse in the deep-channel habitat, including the sternopygids Eigenmannia and Rhabdolichops, and the rhamphichthyid Rhamphichthys (Albert et al., 2011b; Carvalho, 2013). The presence of multiple sympatric congeners within this habitat, including several instances of sister-species pairs, is unusual among Neotropical fishes, where most sister-species pairs are distributed in allopatry (Albert \& Crampton, 2001; Albert \& Reis, 2011; Albert et al., 2011a). The Sternarchellini is part of the diverse assemblage of apteronotid fishes that inhabits the large rivers of tropical South America (Mago-Leccia et al., 1985; Lundberg \& Lewis, 1987). A high proportion (70 of 85 , or $82 \%$ ) of apteronotid species are restricted to the deep channels of the Amazon and Orinoco rivers and their large tributaries. This concentration of species in the deep channels is notable considering the small proportion (2.6\%) of the total bottom area that these channels occupy in the tropical South America (Goulding et al., 2003; Winemiller \& Willis, 2011). Even accounting for the larger volume of large rivers (stream orders 6-10), the total amount of habitat space they occupy is small compared to that of all the small rivers and streams (stream orders 1-5) combined, that drain more than 11 million km² (Albert \& Crampton, 2005a; Crampton \& Albert, 2006; Crampton et al., 2011).

The origin of deep-channel habits by the Navajini, including the Sternarchellini, may have occurred before the separation of the modern Amazon and Orinoco basins, an event that followed the rise of the Vaupes Arch in the Late Miocene (ca. 10-8 Ma; Dobson, 2001; Winemiller \& Willis, 2011). The Navajini includes several clades with multiple sisterspecies pairs and other supraspecific taxa distributed across the Amazon-Orinoco divide. Clades with multiple multispecies assemblages co-exist in both basins (Albert et al., 2011; Albert \& Carvalho, 2011). The Amazon and Orinoco basins are connected on the modern landscape via the Casiquiare Canal, but this waterway probably does not act as a dispersal corridor for most sternarchelline fishes. Sternarchellines are lowland species, and to date no sternarchelline species have been collected from within the Casiquiare Canal or the rivers connected to it above the rapids around the base of Guiana Shield, in either the upper rio Negro or upper río Orinoco basins (i.e., rapids at São Gabriel and Puerto Ayacucho, (Winemiller \& Willis, 2011).

The phylogenetic position of Magosternarchus, nested within Sternarchellini, helps explain the evolution of the extreme phenotypic, behavioral, and ecological specializations of these deep-channel species. The large jaws and robust dentition of Magosternarchus are used in predation, in particular on the tails of other gymnotiforms (Lundberg et al., 1996). Previous studies concluded that Magosternarchus is the sister taxon of the clade composed of Sternarchella (Lundberg et al., 1996), or of Sternarchella and Pariosternarchus (Albert \& Crampton, 2006). Under these 
hypotheses the large jaws, terminal or superior mouth position, and aggressive behaviors of some Sternarchella species are interpreted to have independently evolved from the conditions observed in Magosternarchus. However, according to our phylogenetic results, the genus Sternarchella is found to be paraphyletic, including the two species currently assigned to the genus Magosternarchus (Fig. 9). This result suggests that the large jaws, terminal or superior mouth positions and aggressive predatory behaviors of some Sternarchella species and Magosternarchus are homologous. Five characters support a relationship between Magosternarchus, $S$. schotti and the $S$. terminalis species group: IO less than $20 \% \mathrm{HL}(\mathrm{CI}=0.25)$, anterior mesethmoid straight in lateral view $(\mathrm{CI}=0.50)$, lateral ethmoid large and hour-glass shaped $(\mathrm{CI}=1.00)$, supraoccipital crest dorsal process $(\mathrm{CI}=1.00)$, and endopterygoid process oblique in orientation $(\mathrm{CI}=0.50)$.

\section{Paleogeography and the origin of species in the Sternarchellini}

The paleogeography and geological timeframe over which sternarchelline species originated is poorly constrained, and a time-calibrated phylogeny for the group is not yet available. However, the tree topology (Fig. 9) and geographic distributions (Figs. 10-12) of sternarchelline species do invite inferences regarding aspects of diversification in this clade (Fig. 13). Divergence times of the two Amazon-Orinoco species pairs (S. sima + S. orinoco; S. terminalis + S. orthos) before 10 Ma would imply multiple vicariance events across Vaupes Arch (Fig. 13, right). Alternatively, divergence times of these species pairs after 10 Ma would imply multiple dispersal events across the newly formed Vaupes Arch (Fig. 13, left).

Under a history with more ancient (Middle Miocene or older) divergence times (Fig. 13, right), the origin of the modern basin-wide sternarchelline species-assemblages accompanied the Late Miocene rise of the Vaupes Arch and concomitant breaching of the Purus Arch. If, as we hypothesize above, the Sternarchellini was already present by the Middle Miocene or before, its early divergences could have been affected by the breaching of the Purus Arch (ca. 10-8 Ma), in which the modern Eastern Amazon basin captured the modern Western Amazon basin from the lower proto-Amazon-Orinoco basin (= modern Orinoco basin). The north-flowing proto-AmazonOrinoco (i.e., Subandean) basin, which drained into the Caribbean sea, was the major drainage system of northern South America for most of the early Cenozoic (Lundberg et al., 1998). The presence of two sister-species pairs in the lower portions of the modern Amazon and Orinoco rivers, but not in the Casiquiare Canal or other rivers above the fall line of the Guiana Shield, supports this more ancient, vicariance, hypothesis.

Under the more ancient divergence scenario, inferences can be made about possible extinctions in the area of the modern Orinoco basin. Several sternarchelline taxa (Pariosternarchus, Magosternarchus, S. schotti, and S. calhamazon) occur today only in the Amazon basin. Based on the tree topology presented in Fig. 9, it is possible that

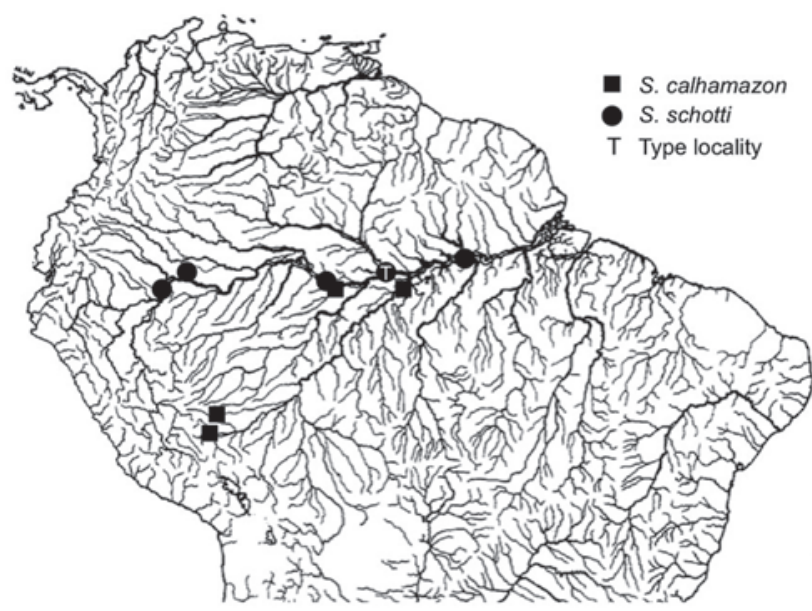

Fig. 10. Distribution map of examined lots of two Sternarchella species. Sternarchella schotti represented as circles, and $S$. calhamazon as squares. Type locality denoted by $\mathrm{T}$.

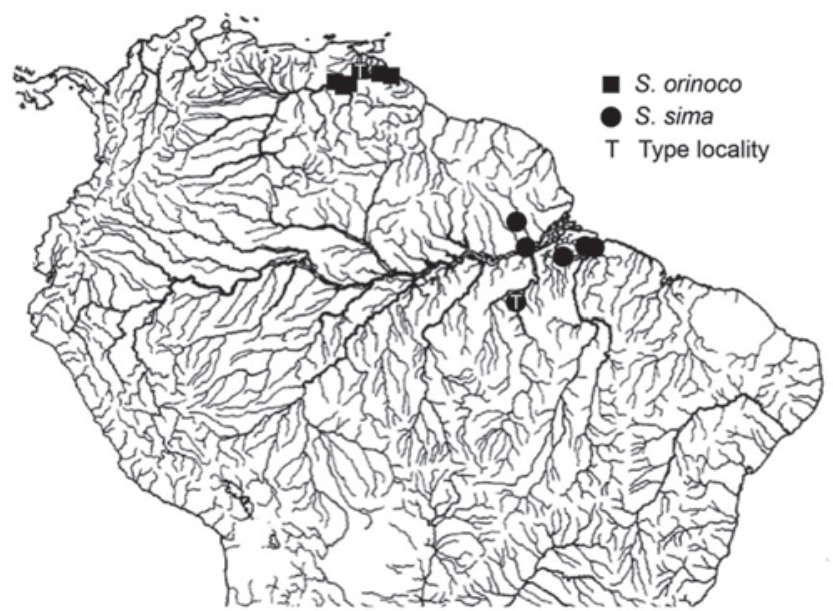

Fig. 11. Distribution map of examined lots of the $S$. sima group. Sternarchella sima represented by circles, and S. orinoco, by squares. Type localities denoted by $\mathrm{T}$.

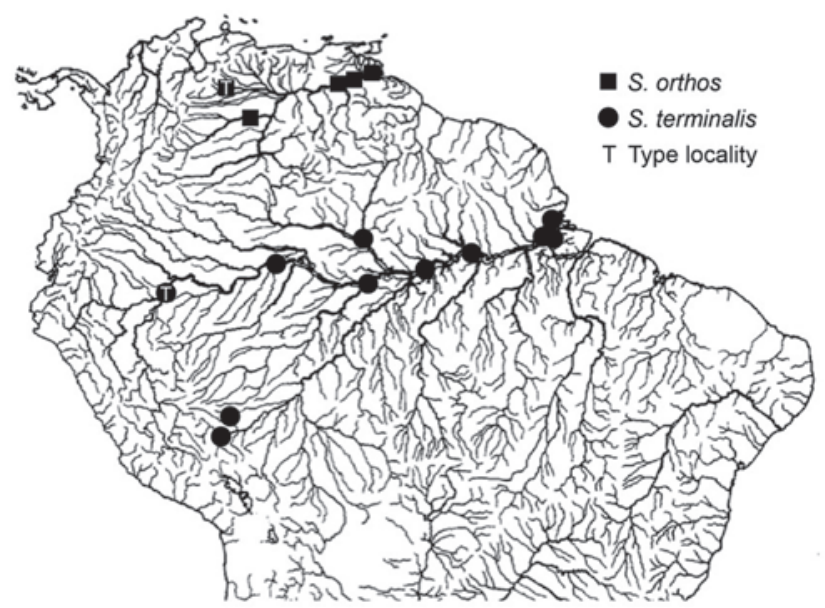

Fig. 12. Distribution map of examined lots in the Sternarchella terminal-mouth species complex. Sternarchella terminalis represented as circles, $S$. orthos as squares. Type localities denoted by $\mathrm{T}$. 


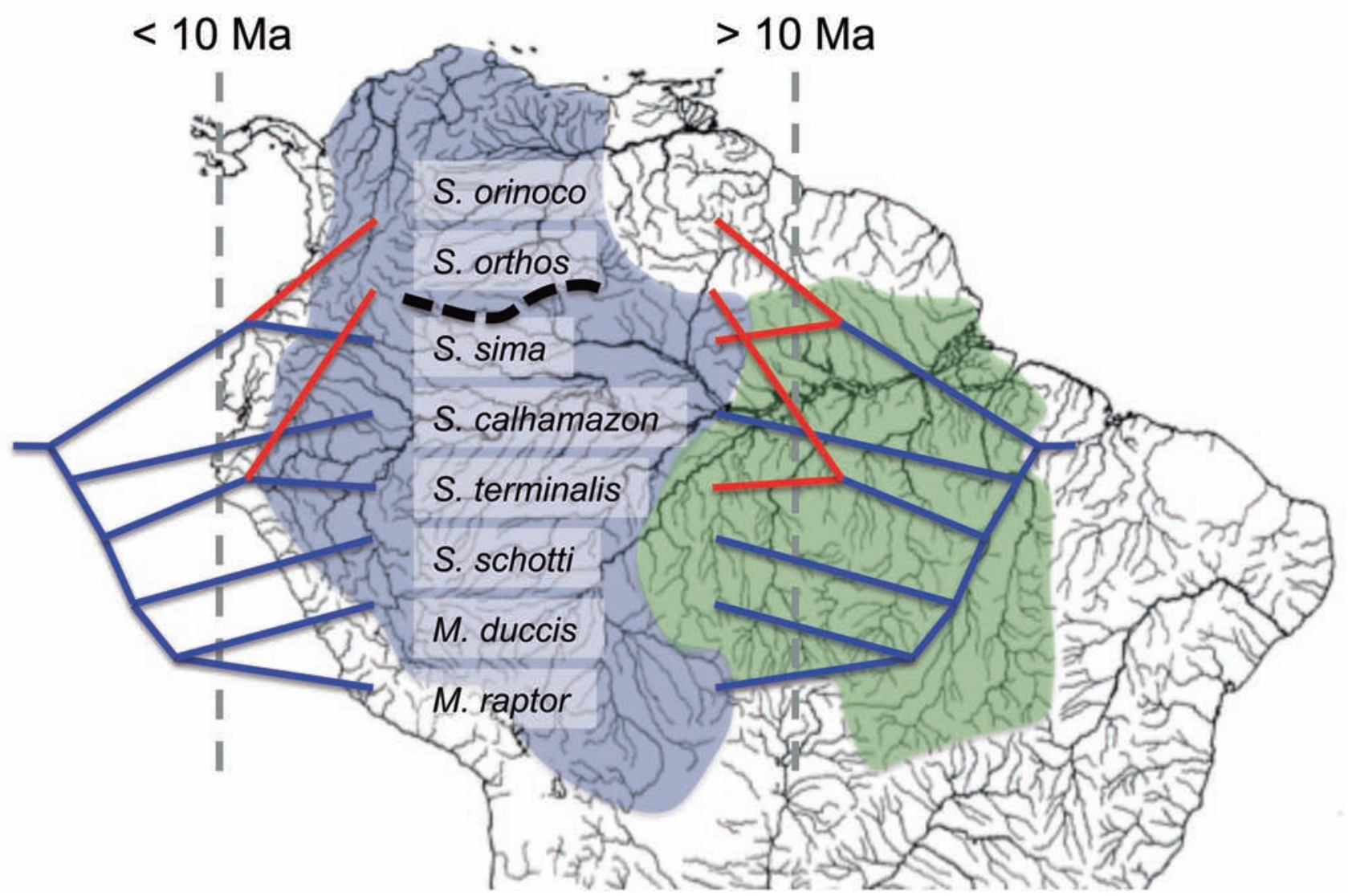

Fig. 13. Alternative time frames for divergences of sternarchelline taxa across the Vaupes Arch. A. Younger divergence (Late Miocene-Pliocene) with multiple dispersal events (red lines) across Vaupes Arch (dashed black line). B. Older divergences (Middle Miocene or older) with multiple vicariance events (red lines) across Vaupes Arch. Tree topology depicted in Fig. 9. Colored regions depict approximate limits of Middle Miocene Amazonian watersheds separated by Purus Arch. Blue: ProtoOrinoco Amazon; Green: Eastern Amazon. Base map by M. Weitzman.

some or all of these taxa originated before the rise of the Vaupes Arch, the event that separated the modern Orinoco and Amazon basins ca. 10 Ma (Lovejoy et al., 2010). Under these conditions, taxa currently absent from the modern Orinoco basin may have been present along the longitudinal extent of the proto-Amazon-Orinoco river system. The hypothesis of widespread extinction of fish taxa from the lower (northern) portions of the proto-Amazon-Orinoco is indicated by the presence of fossilized plates and fin spines of freshwater stingrays (Potamotrygon), lungfish (Lepidosiren), pirarucu (Arapaima), and several families of riverine catfishes from the La Venta Formation (río Magdalena) of Colombia (Lundberg et al., 1998; Albert et al., 2006) and Urumaco Formation (Maracaibo basin) of northern Venezuela. Both formations are located near the paleomouth of the protoAmazon-Orinoco River during the middle Miocene (10-12 Ma). Albert et al. (2011b: 53) reported 91 genera of fishes endemic to the modern Amazon basin that are, by definition, excluded from the modern Orinoco basin. Many of these genera are known as fossils from the Miocene Urumaco Formation, and are now entirely extinct in the modern Orinoco.
Several apteronotid taxa found only in the deep channels of the modern Amazon basin are candidates for having once been present, and later having become extinct, in the area of the modern Orinoco basin. These taxa include Parapteronotus, Pariosternarchus, Magosternarchus, and Orthosternarchus. The absence of these apteronotid taxa in the La Venta and Urumaco Formations should not to be taken as strong evidence that they were in fact absent from these regions. Amazonian lowlands are an exceptionally poor substrate for fossilization, with few ancient (non-floodplain) lakes, and high rates of bioturbation. Most groups of aquatic organisms that live in tropical rainforests are not represented in the fossil record (Lundberg et al., 1998; Lovejoy et al., 2010). Gymnotiformes in general are poorly ossified, lacking plates, spines, or other hard tissues that might become fossilized, and the order as a whole is known as fossils from a few body fragments in just a single locality in Bolivia (Albert \& Fink, 2007). Finally, deep-channel apteronotids like Sternarchellini are especially unlikely to be preserved as fossils, with a highly demineralized endoskeleton that develops a finely reticulated mesh-like texture during growth (Albert, 2001). 
Another possible interpretation for the absence of these sternarchelline taxa in the modern Orinoco basin is that they were simply never present in the northern (lower) portion of the proto-Amazon-Orinoco River, i.e., the llanos basin. There is sedimentological evidence for the presence of several marine incursions into the continental interior during the interval 20-10 M (Lovejoy et al., 2006; Wesselingh \& Hoorn, 2011). These marine incursions may have resulted in local extinctions of strictly freshwater taxa in the northern portion of the proto-Amazon-Orinoco basin, or they may have formed a biogeographic barrier or filter between the northern and southern portions of this basin.

However, a history with less ancient (Middle Miocene or younger) divergence times for the two sternarchelline sisterspecies pairs (i.e., S. sima and S. orinoco, S. terminalis, and $S$. orthos) would imply multiple dispersal events from the Amazon to Orinoco basins (Fig. 13, left). Under this timeframe there is no need to hypothesize extinction events in the Orinoco basin. The Vaupes Arch is indeed a permeable barrier to dispersal for some deep-channel gymnotiform species (e.g., Adontosternarchus balaenops, Sternarchorhamphus muelleri, Steatogenys elegans, Rhamphichthys rostratus), which are known to occur in both the Amazon and Orinoco rivers. Further, and quite aside from the modern connection of the Amazon and Orinoco via the Casiquiare Canal, these two basins are not well-separated physiographically, with a broad lowland corridor joining them on the modern landscape, and a hydrogeographic history of exchanging head-waters via river capture (Winemiller \& Willis, 2011). In fact, the watershed divide between these basins may more profitably be viewed as a semipermeable dispersal filter rather than as an impermeable dispersal barrier for lowland riverine species (Lovejoy et al., 2010). The complete absence of S. sima from the Western Amazon (Gálvis et al., 2006; Crampton, 2011; Ortega et al., 2011; Albert et al., 2012), and the presence of this species in the Negro and upper Orinoco (Winemiller \& Willis, 2011), is consistent with the less ancient dispersal scenario, rather than the more ancient vicariance scenario.

\section{Ecological and phenotypic diversification}

One of the remarkable features of diversity within Sternarchellini is that several closely related species have highly divergent trophic phenotypes (inferior, terminal, or superior mouths). These species coexist geographically (in sympatry) and ecologically (in syntopy), and several species are frequently caught in the same net (Albert \& Crampton, 2005a; Lundberg et al., 2013), indicating that they all live closely together in the deep river channels (Crampton, 2011). Phenotypic disparity in these sternarchellines is observed in the extent of the development of skeletal structures in the head, oral jaws and branchial arches. Some sternarchelline species (i.e., P. amazonensis, S. sima, and S. orinoco) have short and gracile snouts, a round neurocranial vault, and less well-developed oral jaws with smaller conical teeth, all relatively paedomorphic phenotypes. At the other end of the spectrum are species (i.e., M. raptor, M. duccis, S. terminalis, and Sternarchella sp. A) with more peramorphic skeletal development, including robust oral jaw bones and dentition, an elongate neurocranium, few pharyngeal teeth, and small and less numerous gill rakers.

Does the diversity of sternarchelline fishes inhabiting deep Amazonian river channels represent the result of an 'adaptive radiation'? The term 'adaptive radiation' refers to the rapid diversication of a single lineage (i.e., a monophyletic clade) into many phenotypically and ecologically distinct species, usually in association with a substantial increase in morphological and ecological diversity (Simpson 1944; Schluter, 2000). To be 'adaptive', the species divergence results from the action of natural selection, forcing lineages to diverge in functional aspects, like trophic or habitat use. Phenotypic changes can either accompany speciation (e.g., by natural selection in sympatry), or they can develop after lineage splitting in allopatry, subsequently followed by range expansion and ecological co-existence (e.g., Hunt et al., 2007). In an adaptive radiation, phenotypic changes accompany speciation because the speciation results from adaptation (Albert et al., 2011b).

A single sister-species pair in the sternarchelline, in the genus Magosternarchus, live in sympatry according to the phylogeny presented in Fig. 9. In the genus Sternarchella the two documented sister-species pairs are allopatric. However, the absence of Magosternarchus in the Orinoco basin could have resulted from extinction (see above), in which case the distribution of these species would not support a model of sympatric speciation. The morphological disparity between the two extant Magosternarchus species is greater than that of Sternarchella species pairs across the modern Orinoco-Amazon divide, perhaps suggesting a divergence time that pre-dates the $c a .10 \mathrm{MY}$ estimated for the formation of the Vaupes Arch. The hypothesis that Magosternarchus is older than this divide could be tested using divergence time estimates from an analysis of phylogenetic relationships using molecular sequence data (Lovejoy et al., 2010).

There is to date little evidence suggesting habitat partitioning in the deep river channels. The benthic zone of large blackwater and whitewater Amazonian rivers is difficult to study and there is little limnological data on this environment (Val, 1995). However, these deep river environments have no light, have a very swift current, stable oxygen and temperature profiles, low autochthonous production and presumably high predation pressures (Crampton et al., 2011). Biotic inventory data indicate high amounts of longitudinal connectivity (Albert et al., 2011b). Species richness has been shown to be elevated near tributary confluences in deep channel gymnotiforms (Fernandes et al., 2004). None of these observations indicate a suitable set of circumstances for adaptive divergence along habitat or other ecological gradients. Very little is known about breeding in deep channel apteronotids, although several species (e.g., Sternarchorhamphus muelleri) appear to use floodplain 
(varzea) floating meadows as a nursery for eggs and larvae (Crampton, 1998), and this may also be true for some sternarchellines. The hypothesis that phenotypic diversity within the Sternarchellini represents an adaptive radiation would be supported by stable isotope data documenting distinct trophic positions of species within the Amazon river food web (e.g., Layman et al., 2005; Lujan et al., 2011).

Previous studies of diversity in other clades of deep channel apteronotids include taxonomic revisions of Adontosternarchus (Mago-Leccia et al., 1985), Sternarchogiton (de Santana \& Crampton, 2007), Porotergus (de Santana \& Crampton, 2010), and Sternarchorhynchus (de Santana \& Vari, 2010). The first three of these studies did not directly address the ecological and evolutionary topics addressed here, and no formal hypotheses of interrelationships have yet been proposed for these clades (Mago-Leccia et al., 1985; de Santana \& Crampton, 2007; de Santana \& Crampton, 2010). However, multiple species in each of these clades are distributed sympatrically in the Amazon and Orinoco rivers, and stand as candidates for species-pairs that may have diverged in sympatry (Crampton, 2011).

De Santana \& Vari (2010) interpreted diversification in Sternarchorhynchus to be the result of an adaptive radiation. Their phylogenetic results recovered two of eight sisterspecies pairs distributed in sympatry, in the main stems of the Amazon (S. cramptoni and S. rezteri) and Orinoco (S. roseni and S. mendesi) rivers (de Santana \& Vari 2010, fig. 23). However, de Santana \& Vari (2010) did not present functional or ecological data in support of the hypothesis of adaptive divergence among closely related species. More extensive taxonomic reviews of deep channel apteronotid species, in conjunction with species-dense time-calibrated molecular phylogenies, will help further understanding of fish diversity in large rivers of the Amazon and Orinoco basins.

\section{Acknowledgments}

We thank D. Catania (CAS), W. Crampton (UCF), J. Lundberg and M. Sabaj Pérez (ANSP), H. Ortega (MUSM), and R. Vari (USNM) for access to specimens, T. Carvalho, D. Green, E. Maxime, and V. Tagliacollo for discussions, and W. Crampton and an anonymous reviewer for helpful comments to the manuscript. This research was supported in part by National Science Foundation grants 0614334 and 0741450 to JSA.

\section{Literature Cited}

Albert, J. S. 2001. Species diversity and phylogenetic systematics of American knifefishes (Gymnotiformes, Teleostei). Museum of Zoology, University of Michigan, Ann Arbor.

Albert, J. S. 2003. Family Apteronotidae. Pp. 503-508. In: Reis, R. E., S. O. Kullander \& C. J. Ferraris Jr., (Eds.). Checklist of the Freshwater Fishes of South and Central America. Edipucrs, Porto Alegre.

Albert, J. S., \& T. P. Carvalho. 2011. Neogene assembly of modern faunas. Pp. 119-136. In: Historical Biogeography of Neotropical
Freshwater Fishes. Albert, J. S. \& R. E. Reis (Eds.). University of California Press, Berkeley.

Albert, J. S. \& W. G. R. Crampton. 2001. Five new species of Gymnotus (Teleostei: Gymnotiformes) from an Upper Amazon floodplain, with descriptions of electric organ discharges and ecology. Ichthyological Exploration of Freshwaters, 12: 241266.

Albert, J. S. \& W. G. R. Crampton. 2005a. Diversity and phylogeny of Neotropical electric fishes (Gymnotiformes). Pp. 360-409. In: Electroreception. T. H. Bullock, C. D. Hopkins, A. N. Popper \& R. R. Fay (Eds.). Springer Handbook of Auditory Research, Volume 21, Springer-Verlag, Berlin.

Albert, J. S. \& W. G. R. Crampton. 2005b. Electroreception and electrogenesis. Pp. 431-472. In: Evans, D. E. (Ed). The Physiology of Fishes. $3^{\text {rd }}$ ed. CRC Press, New York.

Albert, J. S. \& W. G. R. Crampton. 2006. Pariosternarchus amazonensis: a new genus and species of Neotropical electric fish (Gymnotiformes: Apteronotidae) from the Amazon River. Ichthyological Exploration of Freshwaters, 17: 267-274.

Albert, J. S. \& W. L. Fink. 1996. Sternopygus xingu, a new species of electric fish from Brazil (Teleostei: Gymnotoidei), with comments on the phylogenetic position of Sternopygus. Copeia, 1996: 85102.

Albert, J. S. \& W. L. Fink. 2007. Phylogenetic relationships of fossil Neotropical electric fishes (Osteichthyes: Gymnotiformes) from the Upper Miocene of Bolivia. Journal of Vertebrate Paleontology, 27: 17-25.

Albert, J. S. \& R. E. Reis. 2011. Historical Biogeography of Neotropical Freshwater Fishes. University of California Press.

Albert, J. S., N. R. Lovejoy \& W. G. R. Crampton. 2006. Miocene tectonism and the separation of cis- and trans-Andean river basins: evidence from Neotropical fishes. Journal of South American Earth Sciences, 21: 14-27.

Albert, J. S., P. Petry \& R. E. Reis. 2011b. Major biogeographic and phylogenetic patterns. Pp. 21-58. In: Albert, J. S. \& R. E. Reis (Eds.). Historical Biogeography of Neotropical Freshwater Fishes. University of California Press, Berkeley.

Albert, J. S., T. Carvalho, P. Petry, M. A. Holder, E. Maxime, J. Espino, I. Corahua, R. Quispe, B. Rengifo, H. Ortega \& R. E. Reis. 2011a. Aquatic biodiversity in the Amazon: habitat specialization and geographic isolation promote species richness. Animals, 1: 205-241.

Albert, J. S., T. P. Carvalho, J. A. Chuctaya, P. Petry, R. E. Reis, B. Rengifo, \& H. Ortega. 2012. Fishes of the Fitzcarrald, Peruvian Amazon. Lulu Press, Raleigh, NC.

Barthem, R. B. \& M. Goulding. 1997. The Catfish Connection. Columbia University Press, New York.

Bremer, K. 1988. The limits of amino acid sequence data in angiosperm phylogenetic reconstruction. Evolution, 42: 795803.

Carvalho, T. P. 2013. Systematics and evolution of the toothless knifefishes Rhamphichthyoidea Mago-Leccia (Actinopterygii: Gymnotiformes): diversification in South American freshwaters. Unpublished Ph.D. Dissertation, University of Louisiana at Lafayette, 516p.

Crampton, W. G. R. 1996. Gymnotiform fish: an important component of Amazonian floodplain fish communities. Journal of Fish Biology, 48: 298-301.

Crampton, W. G. R. 1998. Effects of anoxia on the distribution, respiratory strategies and electric signal diversity of gymnotiform fishes. Journal of Fish Biology, 53: 307-330. 
Crampton, W. G. R. 2008. Diversity and adaptation in deep channel Neotropical electric fishes. Pp. 283-339. In: P. Sebert et al. (Eds.). Fish Life in Special Environments. Science Publishers, Enfield, N.H.

Crampton, W. G. R. 2011. An ecological perspective on diversity and distributions. Pp. 165-189. In: Albert, J. S. \& R. E. Reis (Eds.). Historical Biogeography of Neotropical Freshwater Fishes. University of California Press, Berkeley.

Crampton, W. G. R. \& J. S. Albert. 2006. Evolution of electric signal diversity in gymnotiform fishes. Pp. 641-725. In: F. Ladich, S. P. Collin, P. Moller \& B. G. Kapoor, (Eds.). Communication in Fishes. Publishers Inc, Enfield, NH.

Crampton, W. G. R., N. Lovejoy \& J. Waddell. 2011. Reproductive character displacement and signal ontogeny in a sympatric assemblage of electric fish. Evolution, 65: 1650-1666.

Dobson, D. M., G. R. Dickens, \& D. K. Rea. 2001. Terrigenous sediment on Ceara Rise: a Cenozoic record of South American orogeny and erosion. Palaeogeography, Palaeoclimatology, Palaeoecology, 165: 215-229.

Eigenmann, C. H. \& W. Allen. 1922. Fishes of Western South America. University of Kentucky, Lexington.

Eigenmann, C. H. \& D. P. Ward. 1905. The Gymnotidae. Proceedings of the Washington Academy of Sciences, 7: 157-185.

Farris, J. 1989. The retention index and the rescaled consistency index. Cladistics, 5: 417-419.

Fernandes, C. C., J. Podos \& J. G. Lundberg. 2004. Amazonian ecology: tributaries enhance the diversity of electric fishes. Science, 5692: 1960-1962.

Fink, S. V. \& Fink, W. L. 1996. Interrelationships of ostariophysan fishes (Teleostei). Pp. 209-249. In: M. L. Stiassny, L. R. Parenti \& G. D. Johnson (Eds.). Interrelationships of Fishes. Academic Press.

Gálvis, G., J. I. Mojica, S. R. Duque, G. C. Castellanos, P. SánchezDuarte, M. A. Arce, A. Gutiérrez, L. F. Jimenez, M. Santos, S. Vejarano. 2006. Peces del Medio Amazonas. Región de Leticia. Conservation Internacional, Bogota.

Godoy, M. P. de. 1968. Nova espécie de "Sternarchella” Eigenmann (Pisces, Gymnonoti, Sternarchidae). Revista Brasileira de Biologia, 28: 351-355.

Goloboff, P., J. Farris \& K. Nixon. 2008. TNT, a free program for phylogenetic analysis. Cladistics, 24: 774-786.

Goulding, M., R. Barthem, E. Ferreira \& R. Duenas. 2003. The Smithsonian Atlas of the Amazon. Smithsonian Books, Washington, D.C.

Hammer, Ø., D. Harper \& P. Ryan. 2001. PAST-Palaeontological statistics. / pardomv/pe/2001_1/past/pastprog/past.

Hennig, W. 1966. Phylogenetic Systematics. University of Illinois Press, Urbana, IL.

Hillis, D. M. \& J. J. Bull. 1993. An empirical test of bootstrapping as a method for assessing confidence in phylogenetic analysis. Systematic Biology, 42: 182-192.

Hunt, T., J. Bergsten, Z. Levkanicova, A. Papadopoulou, O. St John, R. Wild, P. Hammond, D. Ahrens, M. Balke, M. Caterino, J. Gomez-Zurita, I. Ribera, T. Barraclough, M. Bocakova, L. Bocak \& A. Vogler. 2007. A comprehensive phylogeny of beetles reveals the evolutionary origins of a superradiation. Science, 5858: 1913-1916.

Jolicoeur, P. 1963. The Multivariate Generalization of the Allometry Equation. Biometrics, 19: 497-499.

Jolicoeur, P. \& J. Mosimann. 1960. Size and shape variation in the painted turtle. A principal component analysis. Growth, 24: 339-354.
Layman, C. A., K. O. Winemiller, D. A. Arrington \& D. B. Jepsen. 2005. Body size and trophic position in a diverse tropical food web. Ecology, 86: 2530-2535.

Lujan, N. K., D. P. German \& K. O. Winemiller. 2011. Do wood grazing fishes partition their niche? Morphological and isotopic evidence for trophic segregation in Neotropical Loricariidae. Functional Ecology, 25: 1327-1338.

Lovejoy, N. R., S. Willis \& J. S. Albert. 2010. Molecular signatures of Neogene biogeographical events in the Amazon fish fauna. Pp. 405-417. In: C. M. Hoorn \& F. Wesselingh (Eds.). Amazonia: Landscape and Species Evolution. A Look into the Past. WileyBlackwell; Chichester, Oxford and Hoboken.

Lovejoy, N. R., J. S, Albert \& W. G. R. Crampton. 2006. Miocene marine incursions and marine/freshwater transitions: evidence from Neotropical fishes. Journal of South American Earth Sciences, 21: 1-9.

Lundberg, J. \& W. Lewis. 1987. A major food web component in the Orinoco River channel: evidence from planktivorous electric fishes. Science, 237: 81-83.

Lundberg, J. G. \& F. Mago-Leccia. 1986. A review of Rhabdolichops (Gymnotiformes, Sternopygidae), a genus of South American freshwater fishes, with descriptions of four new species. Proceedings of the Academy of Natural Sciences, 138: 53-85.

Lundberg, J. G., C. C. Fernandes, J. S. Albert \& M. Garcia. 1996. Magosternarchus, a new genus with two new species of electric fishes (Gymnotiformes: Apteronotidae) from the Amazon River Basin, South America. Copeia, 1996: 657-670.

Lundberg, J. G., L. G.Marshall, J. Guerrero, B. Horton, M. C. S. L. Malabarba \& F. Wesselingh. 1998. The stage for Neotropical fish diversification: a history of tropical South American rivers. Pp. 13-48. In: Phylogeny and Classification of Neotropical Fishes. Malabarba, L., R. E. Reis, R. P. Vari, C. A. S. de Lucena \& Z. M. S. de Lucena (Eds.). Museu de Ciências e Tecnologia, Porto Alegre.

Lundberg, J. G., C. C. Fernandes, R. Campos-da-Paz \& J. P. Sullivan. 2013. Sternarchella calhamazon n. sp., the Amazon's most abundant species of apteronotid electric fish, with a note on the taxonomic status of Sternarchus capanemae Steindachner, 1868 (Gymnotiformes, Apteronotidae). Proceedings of the Academy of Natural Sciences of Philadelphia, 162: 157-173.

Madison, W. P. \& D. R. Madison. 2005. MacClade, Analysis of Phylogeny and Character Evolution, version 4.08. Sunderland, Sunderland Associated, Inc, Massachusetts.

Mago-Leccia, F. 1978. Los peces de la familia Sternopygidae de Venezuela. Acta Scientífica Venezolana, 29: 1-51.

Mago-Leccia, F. 1994. Electric fishes of the continental waters of America. Biblioteca de la Academia de Ciencias Físicas, Matemáticas y Naturales, 29: 1-229.

Mago-Leccia F., J. G. Lundberg \& J. N. Baskin. 1985. Systematics of the South American freshwater genus Adontosternarchus (Gymnotiformes, Apteronotidae). Contributions in Science, Los Angeles County Museum of Natural History, 358:1-19.

McElroy, D. \& M. Douglas. 1995. Patterns of morphological variation among endangered populations of Gila robusta and Gila cypha (Teleostei: Cyprinidae) in the upper Colorado River basin. Copeia, 1995: 636-649.

Myers, G. S. 1936. A new genus of gymnotid eels from the Peruvian Amazon. Proceedings of the Biological Society of Washington, 49: 115-116.

Near, T. J., R. I. Eytan, A. Dornburg, K. L. Kuhn, J. A. Moore, M. P. Davis, P. C. Wainwright, M. Friedman \& W. L. Smith. 2012. Resolution of ray-finned fish phylogeny and timing of 
diversification. Proceedings of the National Academy Sciences USA, 109: 13698-13703.

Ortega, H., M. Hidalgo, E. Correa, J. Espino, L. Chocano, G. Trevejo, V. Meza, A. M. Cortijo \& R. Quispe. 2011. Lista anotada de los peces de aguas continentales del Peru. Estado actual del conocimiento, distribución, usos y aspectos de conservación. Museo de Historia Natural, UNMSM, Ministerio del Ambiente, Dirección General de Diversidad Biológica, Lima.

Patterson, C. 1975. The braincase of pholidophorid and leptolepid fishes, with a review of the actinopterygian braincase. Philosophical Transactions of the Royal Society, London (B), 53: 275-579.

Pimentel, R. \& R. Riggins. 1987. The nature of cladistic data. Cladistics, 3: 201-209.

de Santana, C. D. \& W. G. R Crampton. 2007. Revision of the deepchannel electric fish genus Sternarchogiton (Gymnotiformes: Apteronotidae). Copeia, 2007: 387-402.

de Santana, C. D. \& W. G. R. Crampton. 2010. A review of the South American electric fish genus Porotergus (Gymnotiformes: Apteronotidae) with the description of a new species. Copeia, 2010: 165-175.

de Santana, C. D. \& R. P. Vari. 2010. Electric fishes of the genus Sternarchorhynchus (Teleostei, Ostariophysi, Gymnotiformes); phylogenetic and revisionary studies. Zoological Journal of the Linnean Society, 159: 223-371.

Schluter, D. 2000. The ecology of adaptive radiation. Oxford, Oxford University Press.

Simpson, G. G. 1944. Tempo and Mode in Evolution. New York: Columbia University Press.

Starks, E. C. 1913. The fishes of the Stanford Expedition to Brazil. Stanford University Publications.

Steindachner, F. 1868. Die Gymnotidae des K. K. HofNaturaliencabinetes zu Wien. Sitzungsberichte der Kaiserlichen Akademie der Wissenschaften in Wien, 58: 249-264.

Swofford, D. 2003. PAUP*. Phylogenetic Analysis Using Parsimony (* and Other Methods). Version 4. Sinauer Associates, Sunderland, MA.

Taylor, W. R. \& G. Van Dyke. 1985. Revised procedures for staining and clearing small fishes and other vertebrates for bone and cartilage study. Cybium, 9: 107-119.

Triques, M. L. 1993. Filogenia dos gêneros de Gymnotiformes (Actinopterygii, Ostariophysi), com base em caracteres esqueléticos. Comunicações do Museu de Ciências e Tecnologia da PUCRS, Série Zoologia, 6: 85-130.

Triques, M. L. 2005. Análise cladística de caracteres de anatomia externa e esquelética de Apteronotidae (Teleostei: Gymnotiformes). Lundiana, 6: 121-149.

Val, A. 1995. Oxygen transfer in fish: morphological and molecular adjustments. Brazilian Journal of Medical and Biological Research, 28: 1119-1127.

Wesselingh, F. P. \& C. Hoorn. 2011. Geological development of Amazon and Orinoco basins. Pp. 59-67. In: J. S. Albert \& R. E. Reis (Eds.). Historical Biogeography of Neotropical Freshwater Fishes. UC Press, Berkeley.

Weitzman, S. 1974. Osteology and evolutionary relationships of the Sternoptychidae, with a new classification of stomiatoid families. Bulletin of the American Museum Natural History, 153: 327-478.

Wiley, E. O. 1981. Phylogenetics. The theory and practice of phylogenetic systematics. John Wiley \& Sons New York.

Winemiller, K. O. \& S. Willis. 2011. The Vaupes Arch and Casiquiare Canal. Pp. 225-242. In: Albert, J. S. \& R. E. Reis (Eds.). Historical
Biogeography of Neotropical Freshwater Fishes. University of California Press, Berkeley.

Submitted May 9, 2013

Accepted January 7, 2014 by Fabio Di Dario

Published September 30, 2014

APPENDIX 1: Specimens examined for morphometrics and osteology.

Apteronotus albifrons: UF 29921 (4, 2 C\&S), Venezuela, Managas Province, Matooin, Laguna Grande, A. Bolten and K. Bjorndal. Apteronotus bonapartii: MUSM uncat. (AP 2011) (2 C\&S), Peru, Los Amigos Ecological Station, río Los Amigos, Dept. Madre Dios, 2001. M. Goulding. Compsaraia compsus: ANSP 163033 (2 C\&S), Venezuela, Bolivar, río Orinoco, río Orinoco, río Caura confluence, 07³8'36"N 6450’W. ANSP 165223 (2), Venezuela, Apure, río Apure, between río Portuguesa mouth and S. Fernando de Apure. Parapteronotus hasemani: UF 116563 (1), Peru, Maynas, Loreto, rio Amazonas. UF 129334 (1 C\&S), Peru, Loreto, río Pacaya in Reserve Nacional Pacaya Samiria. Porotergus gimbeli: UMMZ 233253 (2 C\&S), Solimões, Brazil. Sternarchogiton nattereri: MUSM uncat. (AP 2011) (2 C\&S) río Madre de Dios near Pto. Maldonado, Dept. Madre de Dios, Peru. Magosternarchus duccis: ANSP 192995 (1 C\&S), Brazil, Amazonas, rio Solimões, below mouth of Purus, 03³5'51;4"S, 06107’40.8"W, 31-July-1996, A. Zanata et al. UF 116561 (1), Peru, Maynas, Loreto, rio Amazonas, 28-March-2001, J. Albert and W. Crampton. USNM 337449 (2), Brazil, Roraima, rio Branco, 3-11 km upriver from confluence with Rio Negro, 10¹6'36"S, 6150'20", 8-December-1993, J. Lundberg et al. Magosternarchus raptor: UF 116762 (1 C\&S), Peru, Maynas, Loreto, Rio Amazonas, 28-March-2001, J. Albert and W. Crampton. USNM 337448 (2), Brazil, Amazonas, rio Solimões, $6.2 \mathrm{~km}$ downriver from confluence with rio Purus, 26-October1993, S. Jewett et al. Pariosternarchus amazonensis: ANSP 192996 (2, 1 C\&S), Brazil, Amazonas, rio Amazonas above Madeira, $11.5 \mathrm{~km}$ downstream of Novo Oriente, $4.4 \mathrm{~km}$ upstream of S. José do Amatari, 3¹7’21"S, 5854’28"W, 13-October-1994, F. Langeani et al. Sternarchella orinoco: USNM 228727 (17, 2 C\&S), Venezuela, Delta Amacuro, río Orinoco, old shipping channel south if Isla Portuguesa nautical mile 117 upstream from sea buoy, 8³6"00’ N, 6148"00’W, 20-February-1978, D. Taphorn et al. USNM 228728 (5), Venezuela, Delta Amacuro, río Orinoco, river channel below mouth of río Arature, naut. mile 53, 8.60, -60.90, 24-Febuary-1978, J. Lundberg et al. USNM 228738 (1), Venezuela, Monagas, deep river channel bottom, 158 naut. mile, 8.5433, -62.3667, 10-November-1979, J. Baskin et al. USNM 228739 (1), Venezuela, Delta Amacuro, shallow river, mouth of Cano Noina, downstream from Arature 51- 52 naut. mile, 8.6194, -60.8733, 18-November-1979, A. Lopez et al. USNM 228740 (3), Venezuela, Bolivar, río Orinoco, deep river channel near Islote de Fajardo, 183 naut. mile upstream from sea, . USNM 228742 (1), Venezuela, Delta Amacuro, río Orinoco, deep river channel near Los Castillos, 161 naut. mile, 16-February-1978, J. Baskin and J. Lundberg. USNM 228744 (2), Venezuela, Delta Amacuro, Boca Grande, 38 naut. mile, 8.625, 
60.6633, 19-September-1979, J. Lundberg et al. USNM 228753 (12), Venezuela, Delta Amacuro, shallow river, Isla Tres Canos, 131.8 naut. mile, 8.6633, -62.02, 11-September-1979, J. Baskin and J. Lundberg. USNM 228754 (2), Venezuela, Delta, río Orinoco, river channel at Isla Portuguesa, 116 naut. mile, 8.60, 61.77, 20-February-1978, D. Taphorn et al. Sternarchella orthos: FMNH 102104, Venezuela, Guárico, río Apure, at Apure both above and below bridge, 12-December-1988, B. Chernoff et al. USNM 228722 (5), Venezuela, Monagas, río Orinoco, river channel in front of ferry station Los Barrancos, 182 naut. mile, 8.38, -62.72, 15-February-1978, J. Lundberg et al. USNM 228725 (8, 2 C\&S), Venezuela, Monagas, río Orinoco, river channel in front of ferry station Los Barrancos, 182 naut. mile, 8.38, -62.72, 15-February-1978, J. Lundberg et al. USNM 228726 (7), Venezuela, Delta Amacuro, río Orinoco, river channel off downstream mouth of Cano Paloma, 91 naut. mile, 8.48, 61.42, 21-February-1978, J. Lundberg et al. USNM 228834 (5), Venezuela, Delta Amacuro, río Orinoco, deep river channel near Los Castillos, 160 naut. mile, 8.53, -62.40, 16-February-1978, J. Baskin et al. USNM 228838 (4), Venezuela, Delta Amacuro, río Orinoco, deep river channel Brazo Imataca, 86 naut. mile, 8.47, -61.33, 22-February-1978, D. Taphorn et al. USNM 228839 (6), Venezuela, Delta Amacuro, río Orinoco, old shipping channel south of Isla Portuguesa, 116 naut. mile, 8.60, -61.77, 20February-1978, D. Taphorn et al. USNM 228840 (5), Venezuela, Delta Amacuro, río Orinoco, deep river channel near Los Castillos, 161 naut. mile, 8.52, -62.40, 16-February-1978, J. Baskin et al. USNM 228871 (8, 2 C\&S), Venezuela, Delta Amacuro, río Orinoco, deep river channel near Los Castillos, 162 naut. mile, 8.52, -62.43, 16-February-1978, J. Baskin et al. USNM 233607 (1), Venezuela, Delta Amacuro, río Orinoco, old shipping channel south of Isla Portuguesa, 116 naut. mile, 8.60, -61.77, 20February-1978, D. Taphorn et al. Sternarchella schotti: FMNH 54565 (5), Brazil, Pará, Santarem, J. D. Haseman. FMNH 115219 (1), Brazil, Para, río Amazonas, between tributaries Parana de Santa Rita and Trombetas, between towns Juruti and Obidos, 0156’07"S, 05541'19"W, 23-October-1994, O. Oyakawa et al. CAS (SU) 54475 (1), Peru, río Ampiyacu, near Pebas, 28November-2001, W. Scherer. UF 26079 (1), Colombia, Meta, Rio Meta, small temporary pond, $15 \mathrm{~km}$ east of Puerto Gaitan, 7-January-1973, H. Boschung et al. UF 116570 (1 C\&S), Peru, Maynas, Loreto, río Amazonas, locality unknown, 28-March2001, J. Albert. Sternarchella sima: AMNH 3864 (1), Paratype, Brazil, Para, Belem market, 1911, E. Starks. ANSP 192107 (1, 1 C\&S), Brazil, Pará, rio Jari, downstream of Monte Dourado, upstream of Bom Jardim, blackwater river type, 13-November1994, L. Py-Daniel et al. ANSP 192108 (2), Brazil, Para, rio Pará above rio Tocantins, $83.3 \mathrm{~km}$ upriver from town of Abaetetuba, $9.1 \mathrm{~km}$ down river from town of Boa Vista, 145'22"S, 49²8'48"W, 18-November-1994, A. Zanata, et al. USNM 373112 (2), Brazil, Pará, rio Tocantins, 11.3 km below Curucabamba. -2.03819, -49.29153, 20-November-1994, A. Zanata et al. USNM 373114 (8, 2 C\&S), Brazil, Pará, rio Amazonas, 15 km above Breves, 16-November-1994, A. Zanata et al. USNM 373318 (2), Brazil, Pará, rio Amazonas, 47 km below Almeirim, 62.5 km above Gurupa, -1.48958, -52.18514, 7-November-1994, A. Zanata et al. Sternarchella terminalis:
FMNH 115218 (1), Brazil, Pará, rio Amazonas, between tributaries Ituqui and Parana de Monte Alegre, between towns Santarem and Monte Alegre, 02 $05^{\prime} 16^{\prime \prime S}, 054^{\circ} 00^{\prime} 28^{\prime \prime W}$, 5November-1994, A. Zanata et al. FMNH 115230 (9), Brazil, Amazonas, rio Solimões, between tributaries Paraná Porto Alegre and Paraná do Saraiva, between towns Petrolina and Siria, 0244'52"S, 066 56'16"W, 14-November-1993, J. Lundberg et al. FMNH 115236 (3), Brazil, Pará, rio Amazonas, between tributaries Furo de Urucuricaia and Paraná dos Arraiolos, between towns Almeirim and Gurupa, 01²9'11"S, 052 09'46"W, 7November-1994, A. Zanata et al. FMNH 115241 (5, 2 C\&S), Brazil, Pará, rio Pará, between tributaries Boa Vista and Tocantins, between towns Boa Vista and Abaetetuba, 01² $45^{\prime} 30^{\prime \prime S}$, 049²9'17"W, 18-November-1994, A. Zanata et al. FMNH 115251 (6), Brazil, Amazonas, rio Madeira, between tributaries Paraná do Maracá and Paraná Ipiranga, between towns Rosarinho and Vila Urucurituba, $03^{\circ} 40^{\prime} 49^{\prime \prime S}, 059^{\circ} 05^{\prime} 31^{\prime \prime W}, 17-$ October1994, J. Lundberg et al. FMNH 115251 (3), Brazil, Pará, rio Amazonas, between tributaries Estreito de Breves and Caruaca between towns Breves and Curralinho, 01 ${ }^{\circ} 47^{\prime} 15^{\prime \prime S}, 050^{\circ} 20^{\prime} 38^{\prime \prime W}$, 17-November-1994, L. Py-Daniel et al. MUSM 45235 (1), Peru, Madre de Dios, río Los Amigos, M. Goulding. MUSM 45236 (2), Peru, Madre de Dios, río Los Amigos, M. Goulding. MUSM 45237 (1), Peru, Madre de Dios, río Los Amigos, M. Goulding. MUSM 45240 (1), Peru, Madre de Dios, río Madre de Dios, J. Albert et al. MUSM 45241 (1), Peru, Madre de Dios, río Madre de Dios, J. Albert et al. USNM 373009 (1), Brazil, Roraima, rio Branco, between Atauba and Caruna, -1.28931, -61.84847. 8December-1993, J. Lundberg et al. USNM 373080 (3), Brazil, Pará, rio Amazonas, 58.5 km below Juruti, 21.1 km above Óbidos, -1.93111, -55.68042, 23-October-1994, O. Oyakawa et al. USNM 373232 (6), Brazil, Pará, rio Amazonas, 22.3 km above Óbidos, -1.92750, -55.65514, 23-October-1994, R. Reis et al. USNM 373316 (2), Brazil, Pará, rio Amazonas, above rio Xingu, Gurupa 41.5 km. -1.44722, -51.98389, 11-November-1994, A. Zanata et al., USNM 375373 (1), Brazil, Amazonas, rio Solimões, -3.59528, -61.12097, 31-July-1996, M. Toledo-Piza et al. USNM 375380 (1), Brazil, Pará, rio Amazonas, 15 km above Breves, 1.59899, -50.55528, A. Zanata. USNM 375385 (1), Brazil, Pará, rio Amazonas, $64.8 \mathrm{~km}$ below Juruti, $9.8 \mathrm{~km}$ above Obidos, 1.91175, -55.54607, 23-October-1994, F. Langeani. Sternarchella calhamazon: MUSM 45230 (1), Peru, Madre de Dios, rio Los Amigos, M. Goulding. MUSM 45231 (4), Peru, Madre de Dios, río Los Amigos, M. Goulding. MUSM 45232 (3), Peru, Madre de Dios, río Los Amigos, M. Goulding. MUSM 45233 (10), Peru, Madre de Dios, río Los Amigos, M. Goulding. MUSM 45234 (1), Peru, Madre de Dios, río Los Amigos, M. Goulding. MUSM 45239 (13), Peru, Madre de Dios, río Madre de Dios, J. Albert et al. USNM 373093 (5), Brazil, Amazonas, rio Amazonas, 11.5 km below Novo Oriente, -3.29056, -58.91514, 13-October1994, F. Langeani. USNM 373113 (10), Brazil, Amazonas, rio Madeira, -3.59819, -58.96875, 6-August-1996, A. Zanata et al. USNM 375373 (5), Brazil, Amazonas, rio Solimões, -3.59528, 61.12097, 31-July-1996, M. Toledo-Piza et al. USNM 375395 (1), Brazil, Pará, rio Trombetas, 9.9 km above Vila Aracua, 1.51500, -56.17014, M. Westneat. 
Appendix 2. Data matrix used in phylogenetic analysis ( $\mathrm{P}$ indicates states $0 \& 1$ ). Characters and states defined in Appendix 4.

\section{Apteronotus albifrons}

011011000000000010011111110000010000 00000100000000000001000001110 ? 0010

\section{Apteronotus macrolepis}

110001001001000010011111110010010001 00000100010000001001101001110 ? 00 ? 0

\section{Compsaraia compsus}

110001100111100000011111110010010001 0000111001100000100100000111111100

Magosternarchus duccis

100000100111102100000101001101121111

P 01111010001010111101111 ? 001111010

Magosternarchus raptor

110100110111100100000111000100121101

0011110100010101011011111001111010

Parapteronotus hasemani

001011000000001000001110000000011000

0000000000000000000000000000 ? 00010

Pariosternarchus amazonensis

000110110111110010001011001010010011

0010110110011011100011001001111110

Porotergus gimbeli

0001110001111110 ? 0101110111010101011

0100111000000000100000100011011100

Sternarchella calhamazon

100110000111112100000001001111010111

0010110100011101111001111001111110

Sternarchella orinoco

100200111111110112000002001110010111

0010110100011001111011011001111110

Sternarchella orthos

100100100111111101000001001101020111

$001111010001010111101 \mathrm{P} 011011111110$

Sternarchella schotti

$1011011101111121000000010011000201 \mathrm{P} 1$

1011110100010101111010011001111011

Sternarchella sima

000210001111110112000002001110010111

0010110100011001100011011001111110

Sternarchella sp. A

10010010011 ? 111101000001001101020111

0011110100010101111011111011111110

Sternarchella terminalis

10010010011 ? 111101000001001101021111

0011110100010101111011111011111110

Sternarchogiton nattereri

0001110011111100 ? 0101110111010101011

0100111001000000100000100011011100
Appendix 3. Summary of character state changes on phylogeny of Figure 9.

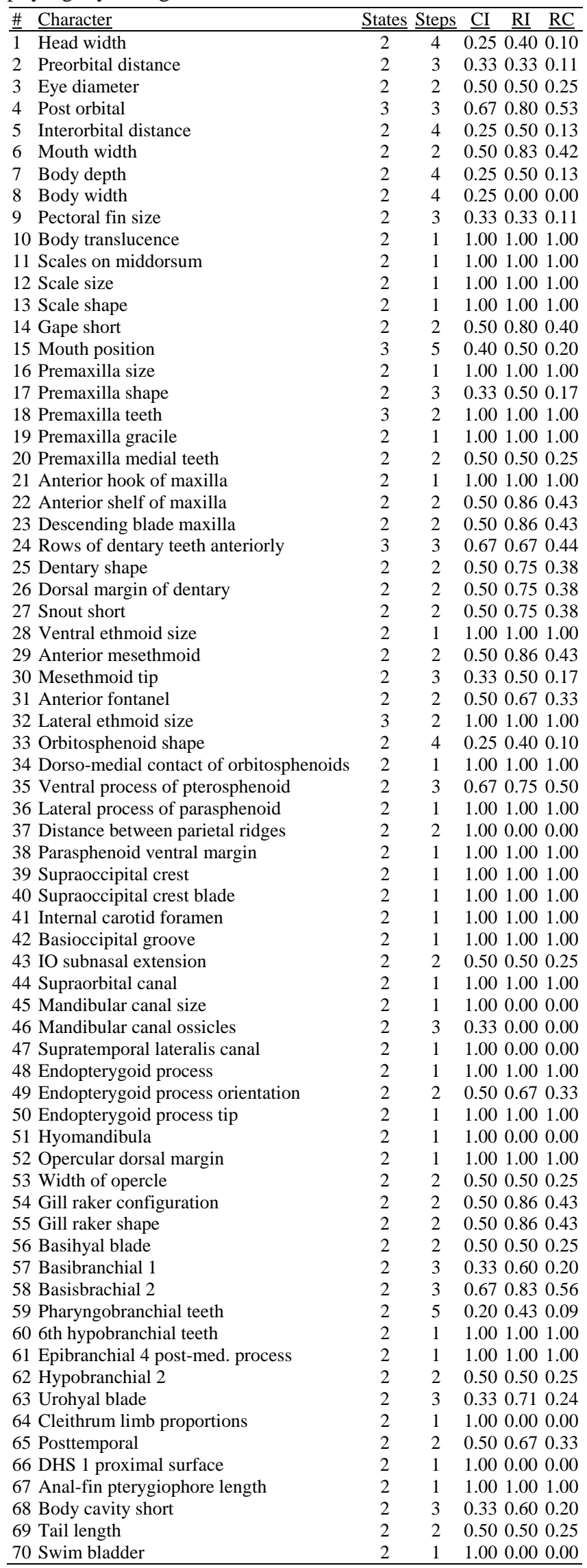


Appendix 4. Characters and character states descriptions.

1. Head width. 0: Head wide, distance between lateral margins greater than 45\% HL. 1: Head narrow, distance between lateral margins less than $45 \% \mathrm{HL}$.

2. Preorbital (snout) length. 0: Preorbital distance small, less than 35\% HL. 1: Preorbital distance large, greater than 35\% HL.

3. Eye diameter. 0: Eye diameter small, less than 8\% HL. 1: Eye diameter large, $8 \% \mathrm{HL}$ or larger.

4. Postorbital distance. 0: Postorbital distance small, less than $60 \%$ HL. 1: Postorbital moderate, between 60 and 66\% HL. 2: Postorbital distance large, 67\% HL and larger.

5. Interorbital distance. 0: Interorbital distance small, less than $20 \%$ HL. 1: Interorbital distance large, $20 \%$ HL or larger.

6. Mouth width. 0: Mouth wide, distance between ricti $18 \%$ HL or greater. 1: Mouth narrow, distance between ricti less than $18 \%$ HL.

7. Body depth. 0: Body depth equal or greater than HL. 1: Body depth less than HL.

8. Body width. 0: Body width greater than $21 \%$ HL. 1: Body width small, $21 \%$ HL or less.

9. Pectoral fin size. 0: Pectoral fin length small, less than $80 \%$ HL. 1: Pectoral fin length large, $80 \%$ HL or greater.

10. Body translucence. 0: Body opaque in living and formalinfixed specimens. 1: Body translucent in living specimens, yellow or pink hue in living specimens.

11. Scales on middorsum. 0 : Scales present on posterolateral portion of body. 1: Scales absent on posterolateral portion of body (Albert, 2001).

12. Scale size. 0: Scales small in size with 9-11 present above lateral line (LL) at midbody. 1: Scales large in size with 5-8 present above lateral line at midbody.

13. Scale shape. 0: Scales dorsal to lateral line ovoid at midbody. 1: Scales dorsal to lateral line rhomboid at midbody (Myers, 1936).

14. Gape short. 0: Rictus extends ventral to nasal capsule, gape more than three times eye diameter. 1: Rictus extends to a vertical with mental symphysis, gape very small, less than twice eye diameter (Albert, 2001).

15. Mouth position. 0: Oral aperture terminal, upper and lower jaws equal in length. 1: Oral aperture superior, lower jaw extends anteriorly to upper jaw. 2: Oral aperture subterminal, upper jaw extends anteriorly to lower jaw (Albert, 2001).

16. Premaxilla size. 0: Small, lateral margin of premaxilla equal to or terminating anterior to articulation of maxilla with autopalatine. 1: Large, lateral margin of premaxilla longer than lateral margin of maxilla (Albert, 2001; fig. 6).

17. Premaxilla shape. 0: Premaxilla triangular in ventral view. 1 : Premaxilla square in ventral view.

18. Premaxilla teeth. 0 : Two, one, or no rows of teeth present on premaxilla. 1: Three rows of teeth present on premaxilla. 2: Four rows of teeth present on premaxilla.

19. Premaxilla size. 0: Premaxilla broad and triangular, three to four rows of irregular teeth. 1: Premaxilla gracile, lateral margin concave, anterior margin laminar, fewer than three rows teeth at its midlength (Albert, 2001; fig. 6).

20. Premaxilla medial teeth. 0: Teeth present on medial anterior portion of ventral surface of premaxilla. 1: Teeth absent on medial anterior portion of ventral surface of premaxilla.

21. Anterior hook of maxilla. 0: Anterior hook of maxilla absent, anterior process broad and triangular with a continuous ventral margin with descending blade. 1: Anterior hook of maxilla present, anterior process extending perpendicular to main axis of maxilla, ventral margin not continuous with descending blade (Lundberg \& Mago-Leccia, 1986).

22. Anterior maxillary shelf. 0: Anterior process of maxilla extending as a shelf of bone less than one-third length of descending blade. 1: Anterior process of maxilla large and broad, extending more than one half length of descending blade in mature specimens (Albert, 2001; figs. 7-8).

23. Descending blade maxilla. 0: Ventral margin of maxillary blade curves evenly towards its distal tip. 1 : Ventral margin of maxillary blade strait to distal tip (Figs. 7-8; Albert, 2001)

24. Rows of dentary teeth anteriorly. 0: Absence of teeth on dentary, presence of a single row of teeth on dentary. 1: Two rows of teeth present on dentary. 2: Three to four rows of teeth present on dentary.

25. Dentary shape. 0: Dentary longer than deep, oral margin of dentary longer than length of angular articular. 1: Dentary deeper than long, oral margin of dentary shorter than length of angular articular (Fig. 10; Albert, 2001).

26. Dorsal margin of dentary. 0: Dorsal margin of dentary slightly concave in lateral view. 1: Dorsal margin of dentary straight or slightly convex in lateral view.

27. Snout length. 0: Length of snout (preorbital length) about one third total head length in adult specimens. 1: Length of snout less than one third total head in adult specimens (Albert, 2001).

28. Ventral ethmoid size. 0: Small with a conical lateral process. 1: Large and robust with a large fan shaped lateral process (Albert, 2001).

29. Anterior mesethmoid. 0: Dorso-anterior portion of mesethmoid straight. 1: Dorso-anterior portion of mesethmoid strongly curved from anterior tip to frontal boundary.

30. Mesethmoid tip. 0: Anterior tip of mesethmoid convex and rounded. 1: Anterior tip of mesethmoid possessing concave divot on dorsal surface.

31. Anterior fontanel. 0: Anterior fontanel longer than posterior fontanel. 1: Posterior fontanel longer than anterior fontanel (Fig. 2).

32. Lateral ethmoid size. 0: Lateral ethmoid thin and tube-like shaped. 1: Lateral ethmoid large hour-glass shaped, most narrow portion at midlength. 2: Lateral ethmoid very robust and large, may contact ventral portion on frontals, hour-glass shaped with most narrow portion at midlength.

33. Orbitosphenoid shape. 0: Orbitosphenoid broad; well ossified in median nasal septum with ventral margin longer than dorsal margin. 1: Orbitosphenoid narrow; anterior portion 
not ossified with ventral margin equal or shorter than dorsal margin (Triques, 1993).

34. Dorso-medial contact of orbitosphenoids. 0: No contact between orbitosphenoids. 1: Dorso-medial portion of orbitosphenoids in contact (visible through anterior fontanel in dorsal view).

35. Ventral process of pterosphenoid. 0: Process originating from ventral portion of most anterior part of pterosphenoid present, sometimes contacting parasphenoid. 1: absence of ventral process of pterosphenoid, anterior ventral margin of pterosphenoid similar to posterior ventral margin of orbitosphenoids.

36. Lateral process of parasphenoid. 0: Large, lateral margins of parasphenoid extending as broad dorsolateral processes anterior to prootic. 1: Small, lateral margins of parasphenoid not extending to a horizontal with trigeminal foramen (Albert, 2001; fig. 16).

37. Parasphenoid ventral margin. 0: Parasphenoid ventral margin straight or slightly curved. 1: Parasphenoid ventral margin sharply angled at base of lateral process.

38. Distance between parietal ridges. 0: Wide with ridges near lateral margins of neurocranium, ridges are less pronounced with a large flat surface between them. 1: Narrow, just lateral to supraoccipital, parietal ridges are very large and pronounced.

39. Supraoccipital crest. 0: Dorsal margin of supraoccipital crest even with dorsal margin of parietals. 1: dorsal margin of supraoccipital crest exceed dorsal margin of parietals.

40. Supraoccipital crest blade. 0: Supraoccipital crest present as a wide blade. 1: Supraoccipital crest extends to a dorsal distal tip.

41. Internal carotid foramen. 0 : Internal carotid foramen large; nearly half size of prootic foramen. 1: Internal carotid foramen reduced.

42. Basioccipital groove. 0: Ventral surface of basioccipital smooth. 1: Shallow groove present on ventral surface of basioccipital.

43. IO subnasal extension. 0 : Anterior portion of infraorbital canal extending anterior from first infraorbital ventral to nasal capsule, anterior canal pore of infraorbital anterior to first infraorbital. 1: Anterior extension of infraorbital canal shorter than width of canal pore, anterior canal pore of infraorbital near first infraorbital (Fig. 19; Albert, 2001).

44. Supraorbital canal. 0: Supraorbital canal fused to frontal. 1: Supraorbital canal not fused to frontal.

45. Mandibular canal size. 0: Mandibular canal size small. 1: Mandibular canal size expanded.

46. Mandibular canal ossicles. 0: Mandibular canal ossicles long slender tubes. 1: Mandibular canal ossicles dumbbellshaped (Albert \& Crampton, 2006).

47. Supratemporal laterosensory canal. 0: Supratemporal laterosensory canal straight, extending dorsally onto posterior portion of parietal, terminal pore oriented dorsoposteriorly, epidermis overlying supratemporal canal indistinguishable from general epidermis. 1. Supratemporal laterosensory canal curved at a sharp angle on surface of parietal, extending posterior onto epaxial surface of body, terminal canal pore oriented posteriorly, epidermis overlying supratemporal canal depigmented (Mago-Leccia, 1994).

48. Endopterygoid process. 0: Endopterygoid process small, not contacting frontal. 1: Endopterygoid large, contacting frontal.

49. Endopterygoid process orientation. 0: Angle of endopterygoid process with dorsal margin of endopterygoid oblique (greater than ninety degrees). 1: Endopterygoid process extends vertically at or near a $90^{\circ}$ angle with dorsal surface of endopterygoid.

50. Endopterygoid process tip. 0: Endopterygoid process slender with a narrow tip. 1: Endopterygoid broadens dorsally with a large tip contacting frontal.

51. Hyomandibula. 0: Hyomandibula long and slender; over twice as long as wide. 1: Hyomandibula short, its width half its length.

52. Opercular dorsal margin. 0: Dorsal margin of opercle straight. 1: Dorsal margin of opercle concave (Fink \& Fink, 1996).

53. Opercle width. 0: Opercle narrow, width approximately half depth. 1: Opercle broad, width over half depth.

54. Gill raker configuration. 0: Base of gill rakers not contacting gill arch. 1. Base of gill rakers contacting gill arch (Albert \& Fink, 1996).

55. Gill raker shape. 0: Gill rakers short with unossified distal tips. 1: Gill rakers long with ossified distal tips (Mago-Leccia, 1978).

56. Posterior ridge of basihyal. 0: Dorsal surface of basihyal flat; small ridge may be present posteriorly. 1: Dorsal surface of basihyal convex forming a robust ridge posteriorly (Triques, 1993).

57. Basibranchial 1. 0: First basibranchial hour-glass with most narrow portion at midlength. 1: First basibranchial fan or rod shaped.

58. Basibranchial 2. 0: Second basibranchial ossified. 1: Second basibranchial unossified.

59. Pharyngobranchial teeth. 0: Fourteen or more teeth present on pharyngobranchial. 1: Twelve or less teeth present on pharyngobranchial.

60. Sixth hypobranchial teeth. 0: Eight or more teeth present on Ceratobranchial. 1: Seven or less teeth present on ceratobranchial.

61. Epibranchial 4 process. 0: Posterior surface of fourth epibranchial flat. 1: Posterior surface of fourth epibranchial with a dorsoventrally oriented process (Triques, 1993).

62. Hypobranchial 4: 0: Medial surface smooth; 1: Medial surface with a process or bridge extending to meet contralateral process on midline.

63. Urohyal blade. 0: Posterior blade of urohyal ossified, extending posterior to fourth basibranchial. 1: Posterior blade of urohyal unossified (Albert, 2001: fig. 32).

64. Cleithrum limb proportions. 0 : Ascending limb of cleithrum length greater than cleithrum anterior limb length. 1. Anterior 
limb of cleithrum length greater than cleithrum ascending limb length.

65. Posttemporal ossification. 0: Posttemporal bone independent from supracleithrum in mature specimens. 1: Posttemporal fused with supracleithrum in mature specimens. 66. Displaced hemal spine (DHS) 1 proximal surface. 0 : Proximal surface of first displaced hemal spine narrower then descending blade. 1: Proximal surface of first displaced hemal spine as broad as descending blade (Albert, 2001).

67. Anal-fin pterygiophore length. 0: At midbody, anal-fin pterygiophore equal to or shorter than hemal spine. 1: At midbody, anal-fin pterygiophore longer than haemal spine (Albert, 2001).

68. Body cavity short. 0: Body cavity short; $12-13$ pre-caudal vertebrae present. 1: Body cavity long; 14-16 pre-caudal vertebrae present.

69. Tail length. 0: Tail long, TL 17\% HL or greater. 1: Tail short, TL less than $17 \%$ HL.

70. Swim bladder. 0: Swim bladder not extending posterior to body cavity. 1: Swim bladder elongate past posterior limit of body cavity. 